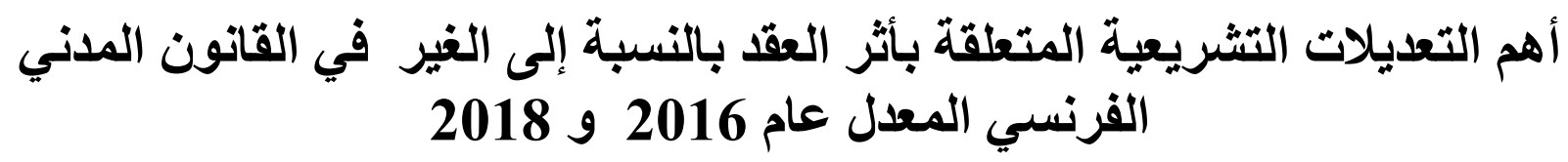
(دراسة مقارنة)

\author{
رغيد عبد الحميد فتتال \\ جامعة عجمان ـ الإمارات العربية المتحدة
}

raghid.fattal@gmail.com

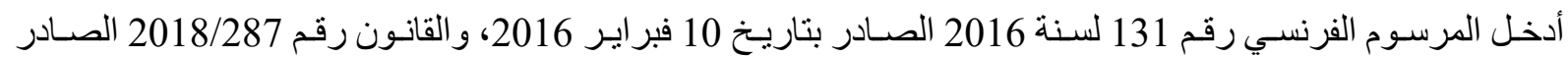

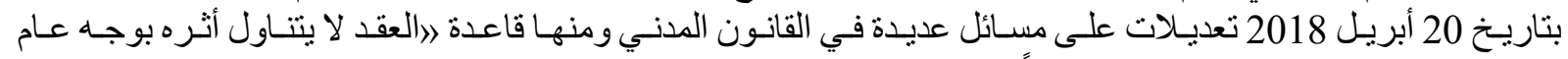

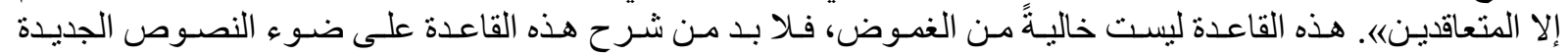

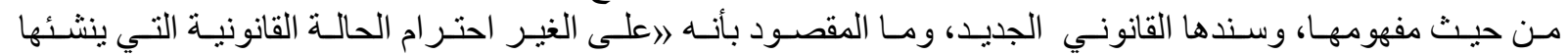

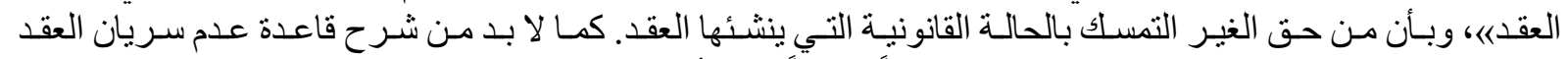

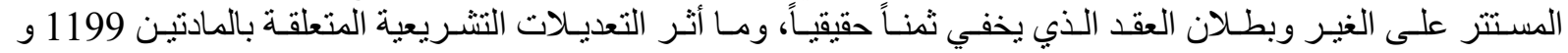

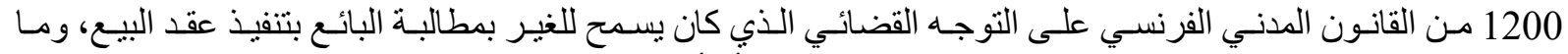

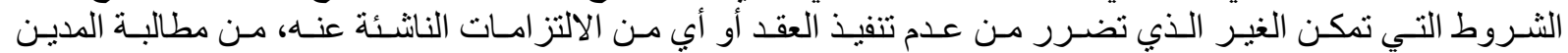

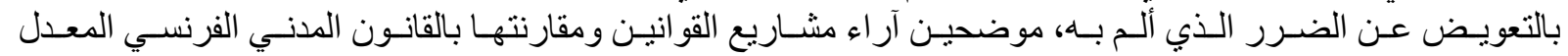

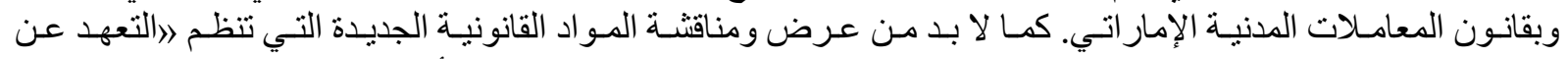

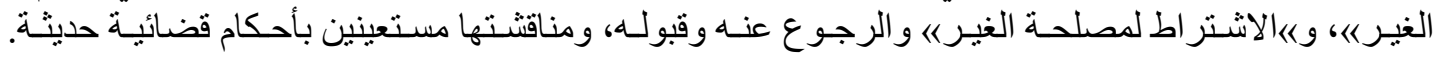

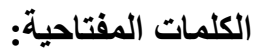

المرسـوم الفرنسـي رقم 131 لسـنة 2016؛ القانون رقم 2018/287؛ أتثر العقد بالنسبة إلى الغيـر ؛ التعهد عن الغير؛

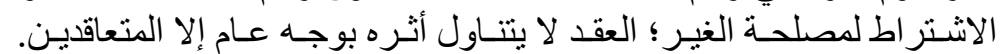




\title{
The Most Important Legislative Amendments Related to the Effect of the Contract Towards the Third Party in the French Civil Code Amended in 2016 and 2018
}

(Comparative Study)

\author{
Raghid Fattal \\ Ajman University - UAE \\ raghid.fattal@gmail.com
}

\begin{abstract}
The French decree no. 131/2016 promulgated on Feb.10, 2016, and the Law no. 287/2018 promulgated on April 20, 2018 have amended many issues in the French Civil Code, including the doctrine "the contract has effect towards the parties only". However, this doctrine is not very clear, and needs to be interpreted according to the new legislations. This shall include the idea that "the third party shall respect the legal status created by the contract", and the idea that the third party can benefit from the legal status created by the contract as well.

The doctrine according to which the simulated contract does not have effect towards the third party, and the nullity of the contract that simulates the true price, and how the amendments of the articles 1199 and 1200 of the French Civil Code affect the courts decisions that allow the third party to oblige the seller to execute the sale contract. It is also important to mention the conditions that allow the third party to sue for damages, the debtor who did not perform his/her contractual duties. We would like also to mention the opinions of the Law projects makers, and to compare the laws with the UAE Civil Transactions Law. The new doctrine of "binding himself on behalf of a third party" and the doctrine of "stipulation for the benefit of a third party" shall be interpreted according to the new legislations.
\end{abstract}

\section{Keywords}

The French decree no. 131/2016; Law no. 287/2018; effect of a contract towards the third party; stipulation for the benefit of a third party; binding himself on behalf of a third party. 


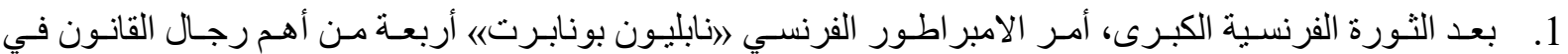

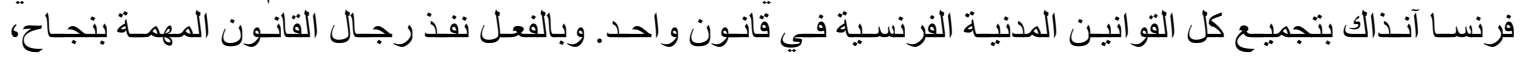

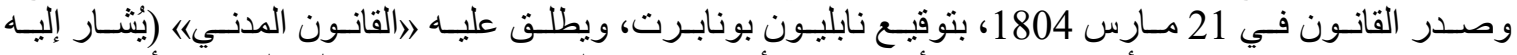

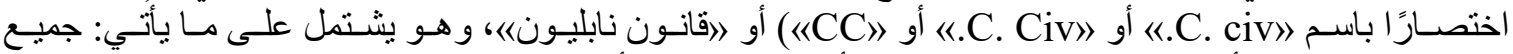

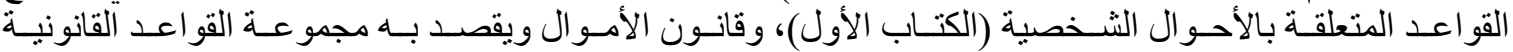

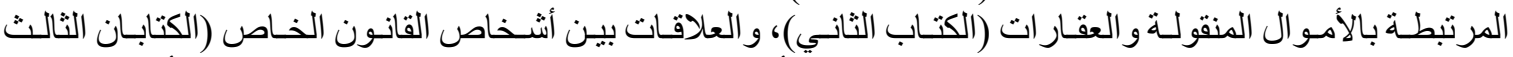

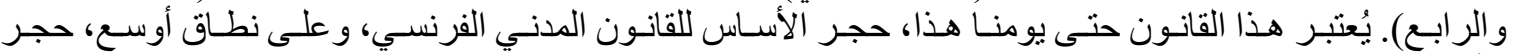

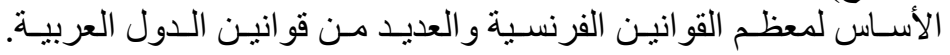

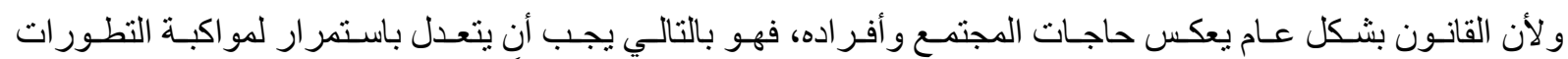

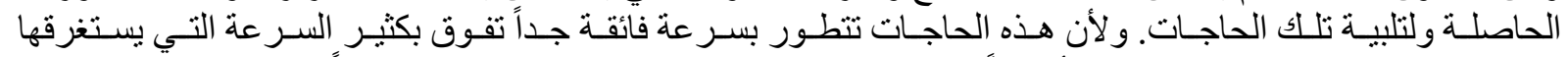

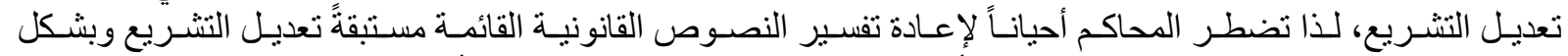

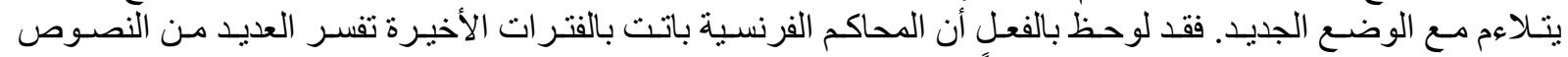

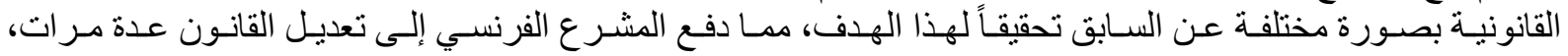

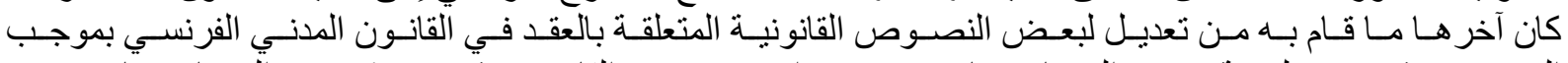

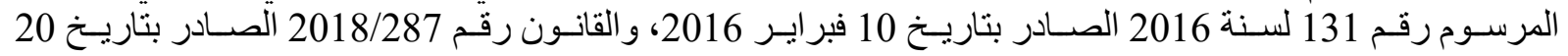

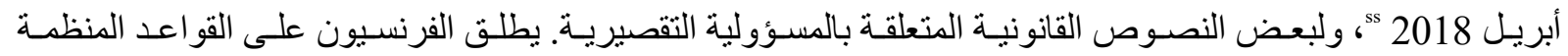

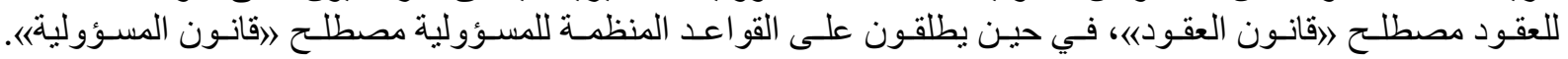

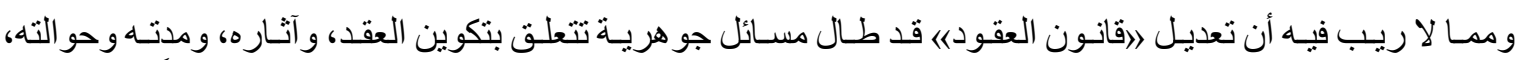

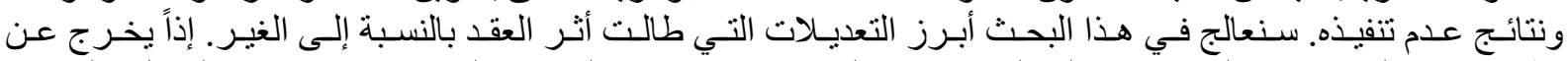

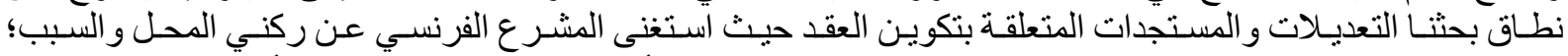

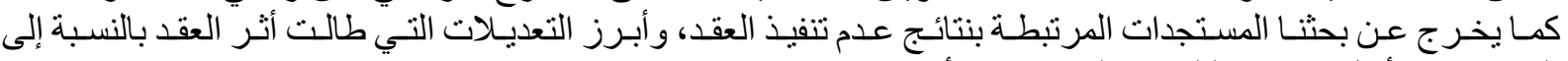
المتعاقديـن. نأمـل در اسـة ذلك في في القـادم مـن الأبحـاث.

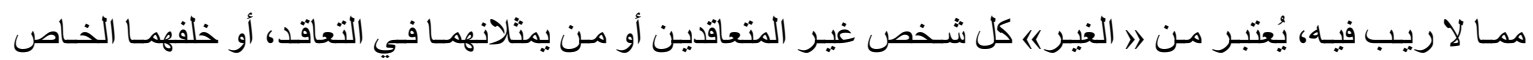

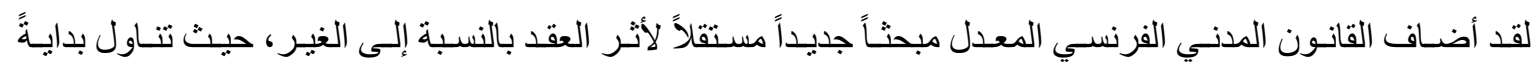

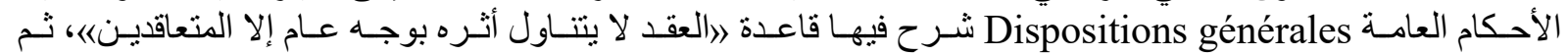

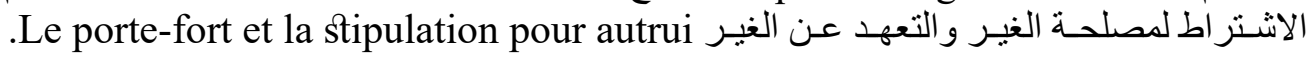

الإشكاليات وأهمية البحث

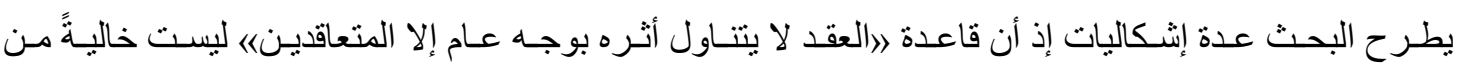

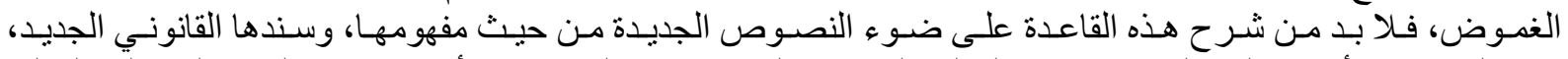

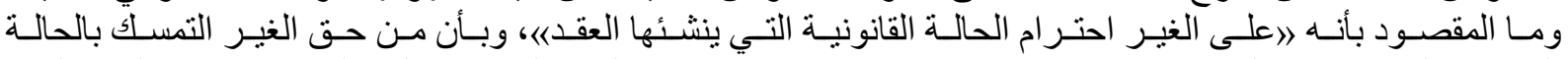

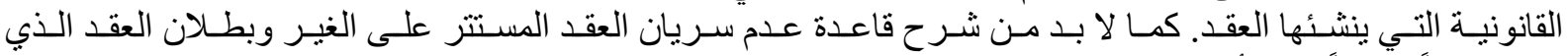

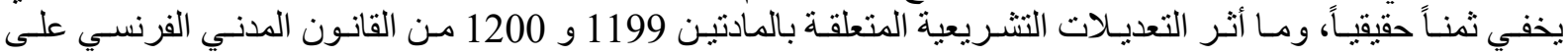

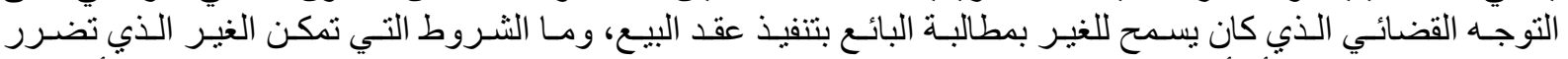

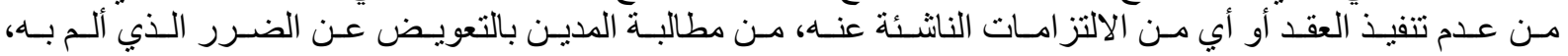

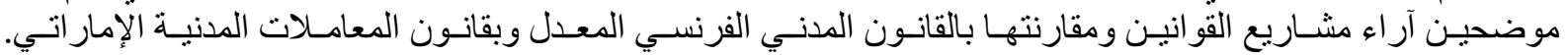

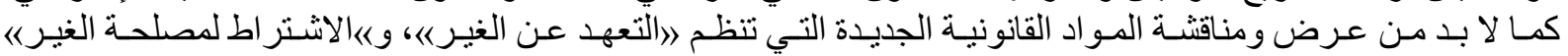

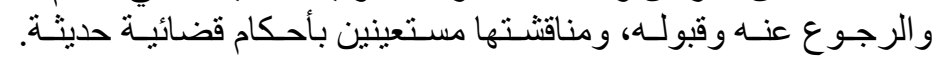

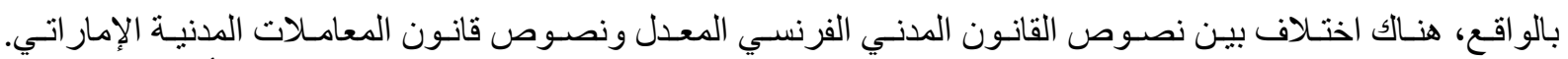

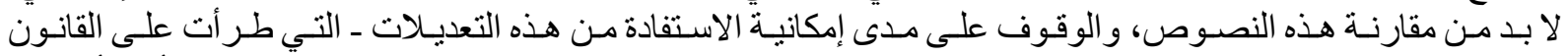

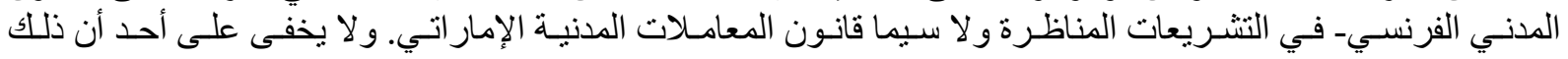


في غايـة الأهميـة، لمـا فيهـا مـن اسـتفادة مـن تجـارب الآخرين وقو انينهم، فيمكنــا أخذ مـا هـو مفيد لمجتمعاتتـا، و إقصـاء

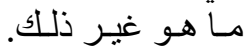

المنهج وخطة البحث

سنعالج الإشكاليات المطروحة عبر اتباع المنهج الوصفي التحليلي والمقارن، حيث سنستعرض تباعاً:

المبحث الأول: شرح قاعدة 》العقد لا يتناول أثره بوجه عام إلا المتعاقدين《)

\begin{abstract}
2.

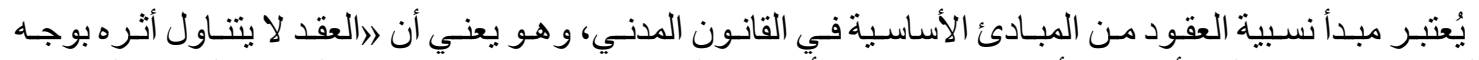

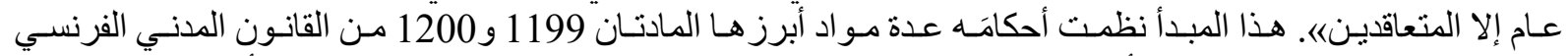

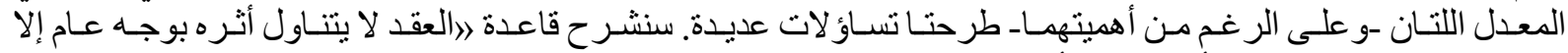

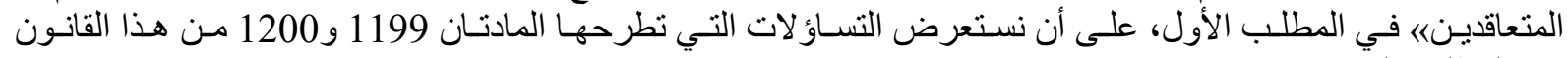
في المطلاب الثاني.
\end{abstract}

\title{
المطلب الأول: مفهوم قاعدة "العقد لا يتناول أثره بوجه عام إلا المتعاقدين،؛
}

Ss S. PELLE, «L'effet relatif et l'opposabilité du contrat » in Quel renouveau pour le droit des contrats ?, Dalloz, 2018, p. 143.

ss L'article 1199 de code civil réformé dispose :

"le contrat ne crée d'obligations qu'entre les parties.

Les tiers ne peuvent ni demander l'exécution du contrat ni se voir contraints de l'exécuter, sous réserve des dispositions de la présente section et de celles du chapitre III du titre IV".

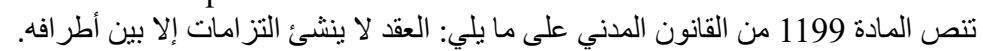

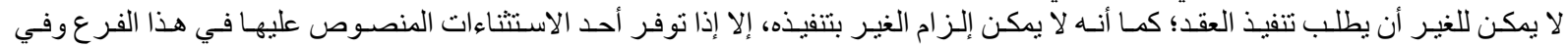
فروع الفصل الثالث من الباب الر ابعه).

Ss Cour de cassation, civile, Chambre civile 1, 21 mars 2018, 17-13.163, Inédit.

ss Cour de cassation, civile, Chambre civile 1, 9 janvier 2019, 17-14.492 17-17.195, Inédit ; Cour de cassation, civile, Chambre civile 1, 9 janvier 2019, 17-27.41; Cour de cassation, civile, Chambre civile 3, 17 mai 2018, 17-16.146, Inédit. 


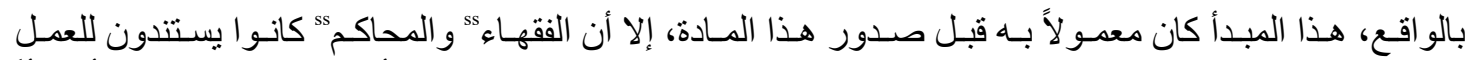

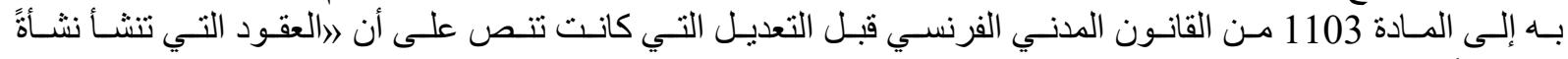

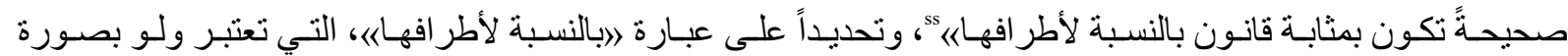

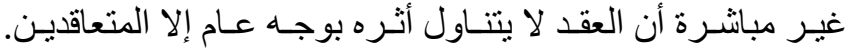

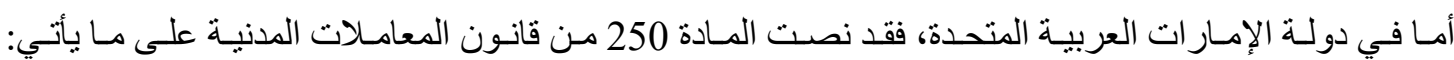

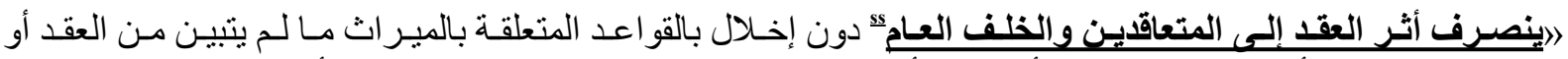

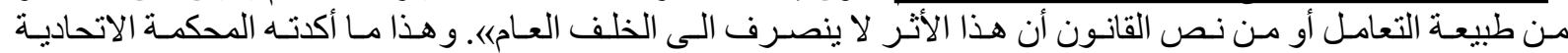

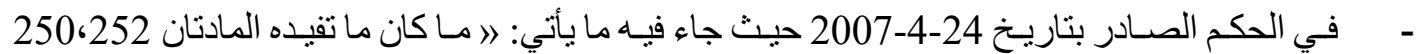

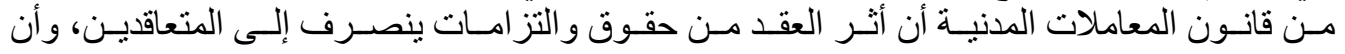

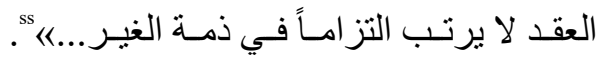

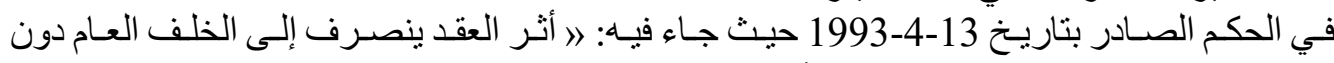

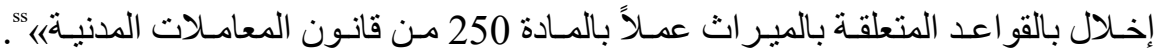

كما أكدت على ذلك محكمة تمييز دبي:

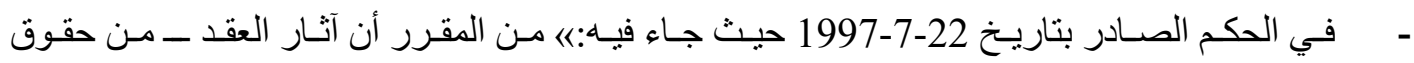

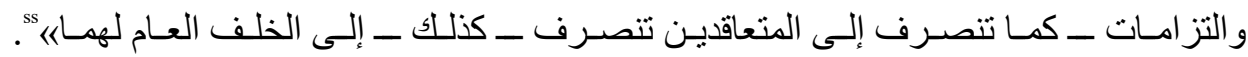

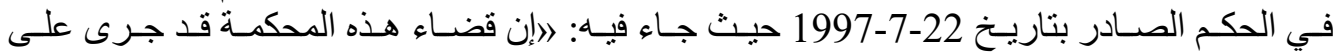

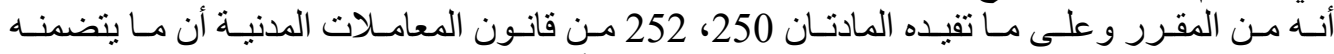

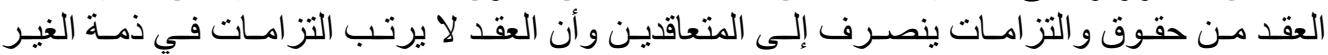

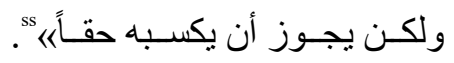

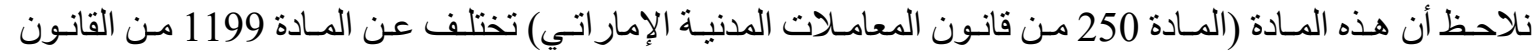

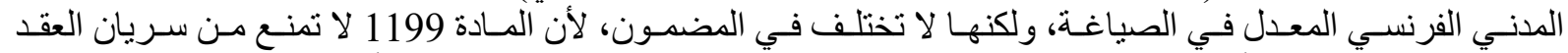

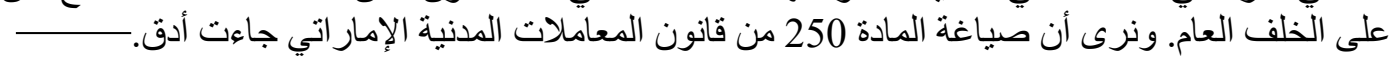

SS S. PELLE, «L'effet relatif et l'opposabilité du contrat » in Quel renouveau pour le droit des contrats ?, p. 146.

ss Cour de cassation, chambre civile 1, Audience publique du jeudi 19 mars 2015, $\mathrm{N}^{\circ}$ de pourvoi: 13-27199, Non publié au bulletin.

ss L'article 1103 de Code civil avant la réforme dispose:

"Les contrats légalement formés tiennent lieu de loi à ceux qui les ont faits".

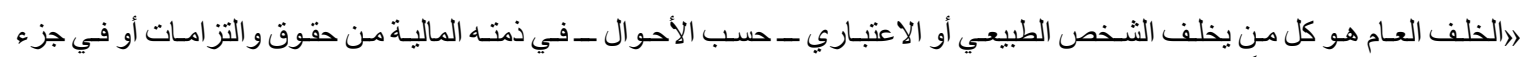

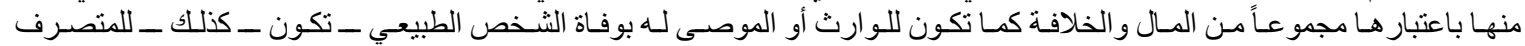

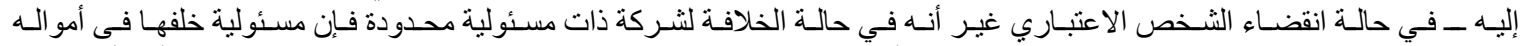

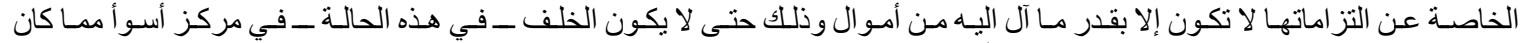

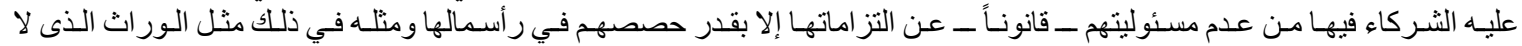

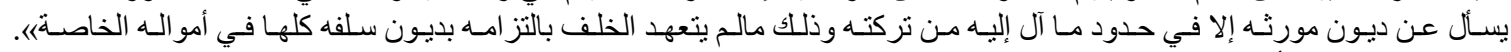

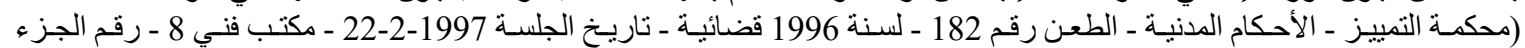

1 - م رقم الصفحـة 110).

SS المحكمة الإتحادية العليا ـ الأحكام الددنية و التجارية ـ الطعن رقم 378 ـ لسنة 28 قضائية ـ تاريخ الجلسة 2007-4-24 - مكتب فني 29 رقم الصفحة 347.

المحكمة الإتحادية العليا ـ الأحكام الددنية والتجارية ـ الطعن رقم 156 ـ لسنة 14 قضائية ـ تاريخ الجلسة 1993-4-13 ـ مكتب فني 15 رقم الجزء 2 - رقم الصفحة 662.

ss محكمة التمييز - الأحكام الدننية ـ الطعن رقم 182 ـ لسنة 1996 قضائية ـ تاريخ الجلسة 1997-22-22 - مكتب فني 8 - رقم الجزء 1 - رقم الصفحة 110.

ss محكمة التمييز - الأحكام المدنية ـ الطعن رقم 328 ـ لسنة 2004 قضائية ـ تاريخ الجلسة 2005-27-3 ـ مكتب فني 16 - رقم الجزء 1 رقم الصفحة 648. 


\section{4. - على الغير احترام الحالة القانونية التي ينشئها العقد.}

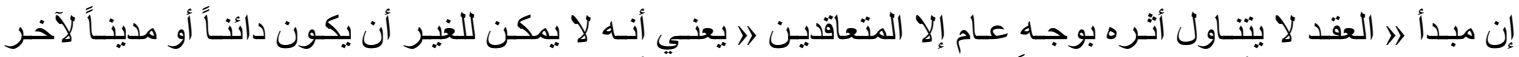

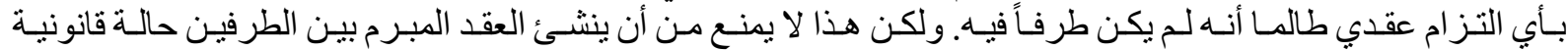

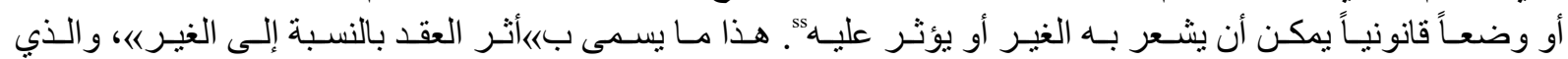

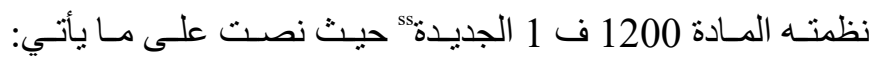

$$
\text { ״- إلى الغير احتر ام الحالة القانونية (الوضع القانوني) التي ينشئها العقد). }
$$

بالنسبة للعقود التـي محلهـا إنشـاء أو نقل حق عينـي، أصليـاً كان أم تبعبـا، يكون أثر هـا تجـاه الجميع، وبالتالي تجـاه

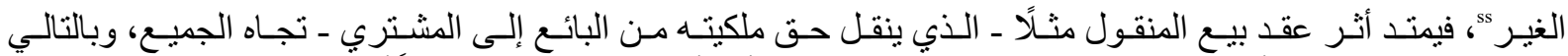

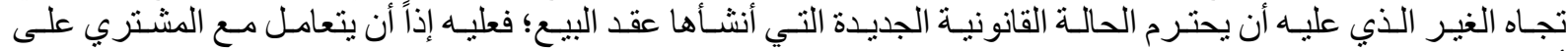
أنسه الماللك الجديد للمنقول محل عقد اليبع.

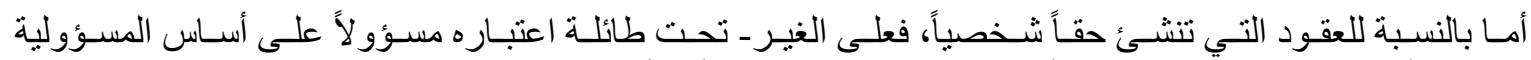

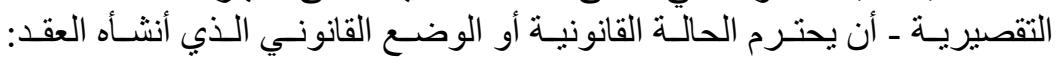

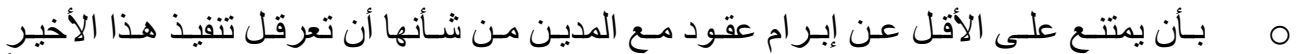

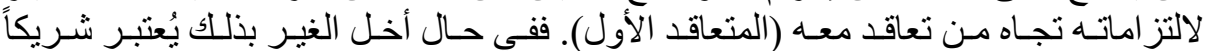

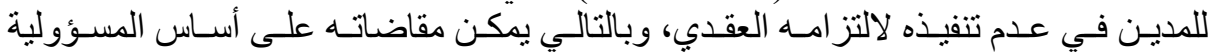

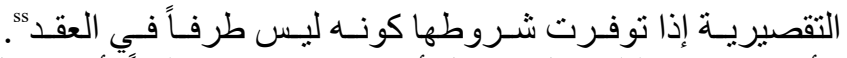

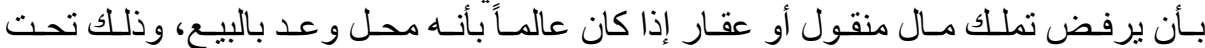

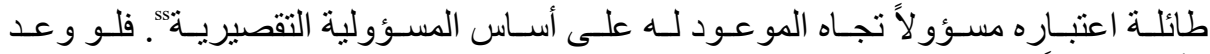

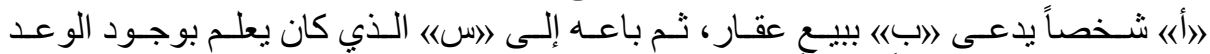

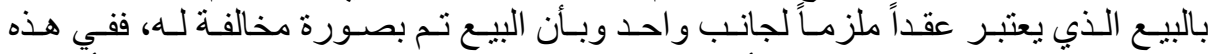

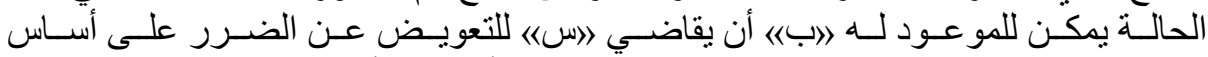

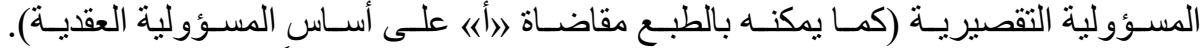

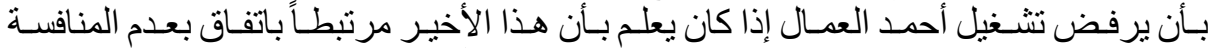

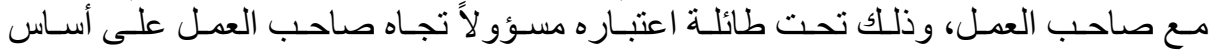

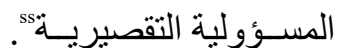

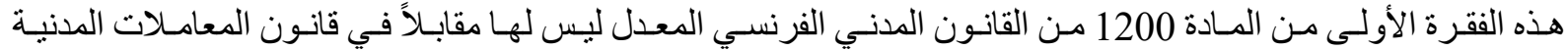

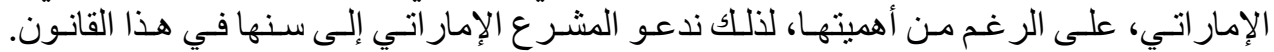

ss Terré Fr., Simler Ph., et Lequette Y., Droit civil. Les obligations, Dalloz, 11éd., 2013, nº 490.

ss L'article 1200 al. 1 de code civil réformé dispose :

"Les tiers doivent respecter la situation juridique créée par le contrat".

$$
\text { تتص المادة } 1200 \text { ف } 1 \text { من القانون المدني المعدل على ما يلي: العي: }
$$

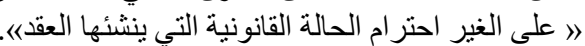

Flour J., Aubert J.-L. et Savaux É., Droit civil. Les obligations. L'acte juridique, t. I, Sirey, 16e éd., 2014, no 434.

ss $\quad$ Cass. $3^{\text {e }}$ civ., 8 juill. 1975, $\mathrm{n}^{\circ}$ 73-14.486, Bull. civ. III, n²49 ; Cass. $1^{\text {re }}$ civ., 26 janv. 1999, $\mathrm{n}^{\circ}$ 96-20.782, Bull. civ. I, n³2, RTD civ. 1999, p. 625, obs. Mestre J. ; Cass. com., 20 juin 1972, n 71-11.151, Bull. civ. IV, no 198 ; rappr. C. trav., art. L. 1237-3 ; Cass. com., 30 nov. 1999, no 97-13.249, RJDA 2000, no 129 ; Cass. $1^{\text {re }}$ civ., 17 oct. 2000, no 97-22.498, Bull. civ. I, nº 246, D. 2001, p. 952, note Billiau M. et Moury J., JCP G 2001, I, n 338, obs. Viney G.

ss $\quad$ Cass. 3e civ., 8 juill. 1975, no 73-14.486, Bull. civ. III, no 249.

d'un pacte de préférence (voir nos 211 et s. et 229 et s. 


\section{5.من حق الغير التمسك بالحالة القانونية التي ينشئها العقد}

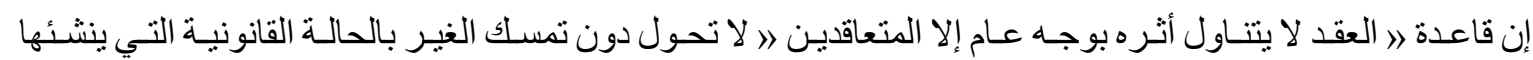

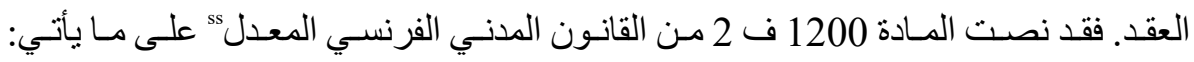

״-2 من حق الغير التمسك بالحالة القانونية التي ينشئها العقد خاصةً من جهة إثبات الو اقعة القانونيةه؛.

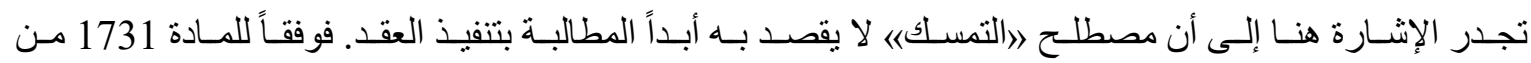

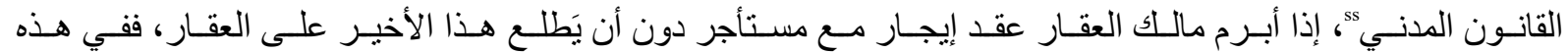

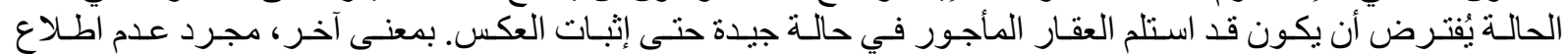

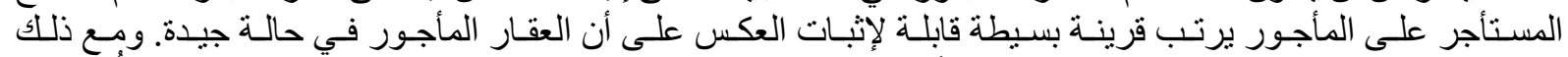

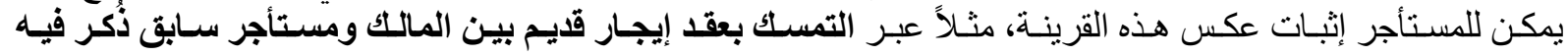

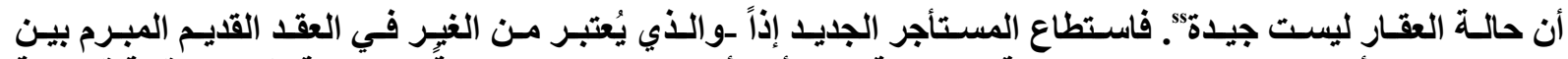

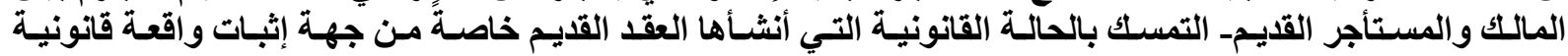
تتمثل بسـوء حالـة المأجور.

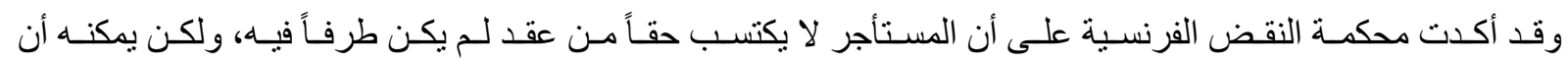

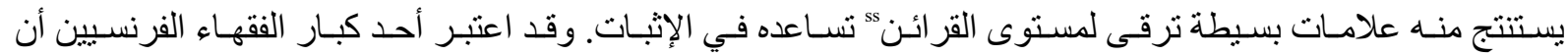

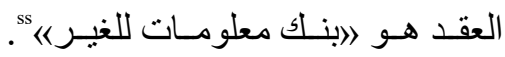

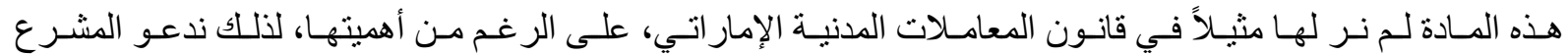

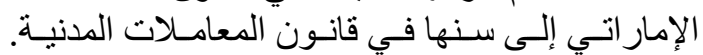

\section{6}

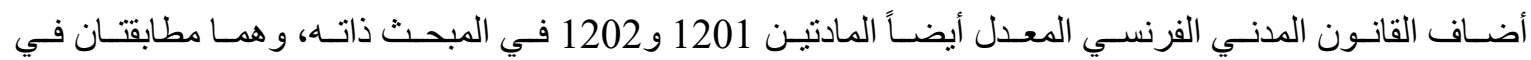

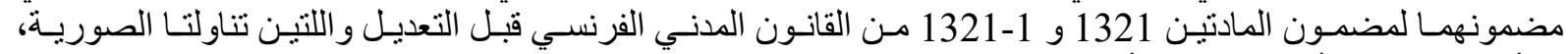

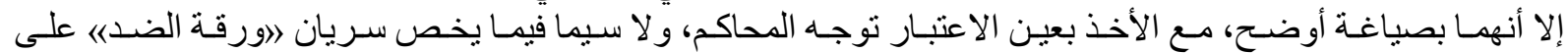

لقد اعتبرت المـادة $1201^{\text {ss }}$ من القانون المدنـي الفرنسـي المعدل أنسه إذا أبرم المتعاقدان عقداً صوريـاً يخفي عقداً

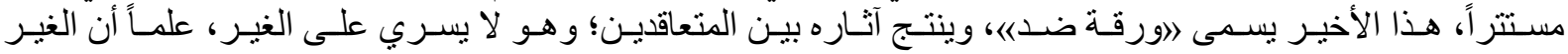

ss L'article 1200 al. 2 de code civil réformé dispose :

"Ils (les tiers) peuvent s'en prévaloir notamment pour apporter la preuve d'un fait".

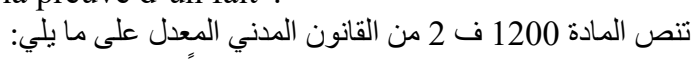

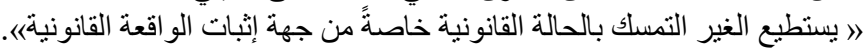

ss Voir C. civ., art. 1731 ; rappr. L. no 89-462, 6 juill. 1989, JO 8 juill., art. 3-2.

"S'il n'a pas été fait d'état des lieux, le preneur est présumé les avoir reçus en bon état de réparations locatives, et doit les rendre tels, sauf la preuve contraire".

ss Terré Fr., Simler Ph. et Lequette Y., Droit civil. Les obligations, Dalloz, 11e éd., 2013, no 496.

ss "Le preneur ne se proposait pas de dégager de l'acte auquel il n'avait pas été partie un lien de droit à son profit mais seulement d'y puiser de simples renseignements susceptibles d'engendrer des présomptions favorables à sa cause » (Cass. req., 27 juill. 1896, DP 1997, I, p. 327).

ss Delebecque Ph., note sous Cass. 1re civ., 3 janv. 1996, no 93-20.404, Defrénois 1996, art. 36381-105.

ss L'article 1201 de code civil réformé dispose que:

"Lorsque les parties ont conclu un contrat apparent qui dissimule un contrat occulte, ce dernier, appelé aussi contre-lettre, produit effet entre les parties. Il n'est pas opposable aux tiers, qui peuvent néanmoins s'en prévaloir".

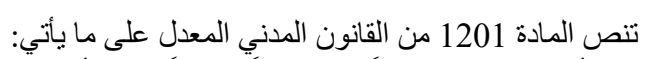

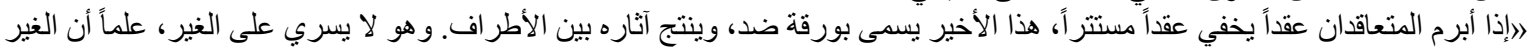
يستطيع التمسك بهان. 
أما المشرع الإمار اتي فقد نص في المادة 394 من قانون المعاملات المدنية على ما يأتي:

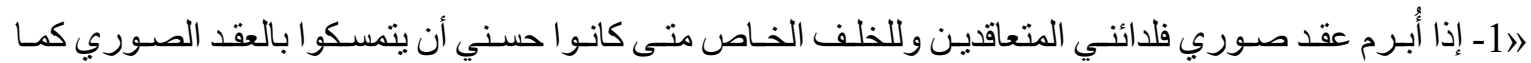

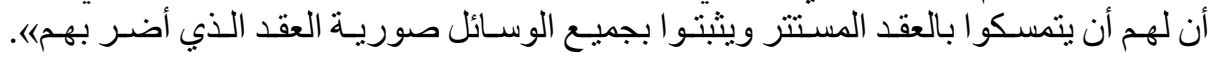

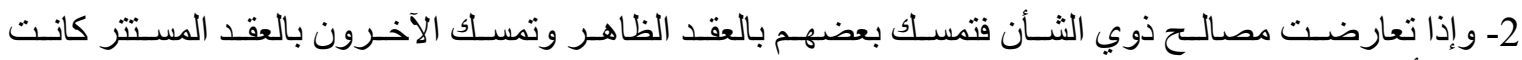
الأفضليـة للأوليـنهان أنعاره.

\section{كما تتص المادة 395 من قانون المعاملات المدنية على ما يأتي:}

》إذا ستر المتعاقدان عقداً حقيقياً بعقد ظاهر فالعقد النافذ بين المتعاقدين والخلف العام هو العقد الحقيقي《. يتبيـن مـن هذه المـادة 394 مـن قانـون المعامـلات المدنيـة أن لدائنـي المتعاقديـن و الخلف الخـاص (وهـ مـن الغيـر )

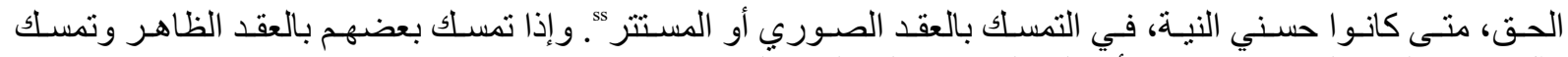

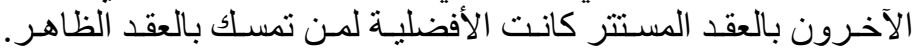

إن أوجـه الشـبه بيـن المادتيـن 394 و395 مـن قانــون المعامـلات المدنيـة الإمار اتـي مـن جهـة، و المـادة 1201 مـن القانـون المدنـي الفرنسـي المعـدل مـن جهـة أخـرى تكمـن بالآتـي: - - - العقد المستتر هو الذي ينتج آثاره بين المتعاقدين.

أمـا أوجـه الاختـلاف بيـن المادتبـن 394 و 395 مـن قانـون المعامـلات المدنيـة الإمار اتـي مـن جهـة، والمـادة 1201 مـن القانـون المدنـي الفرنسـي المعدل تكمـن بالآتـي:

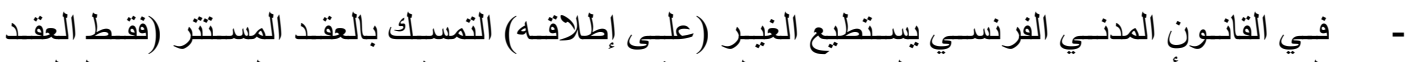

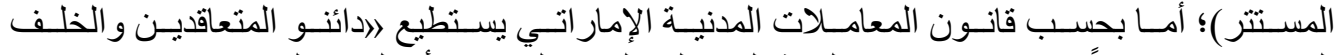

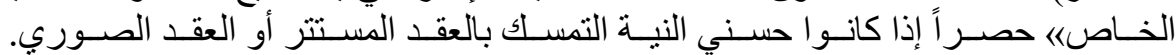

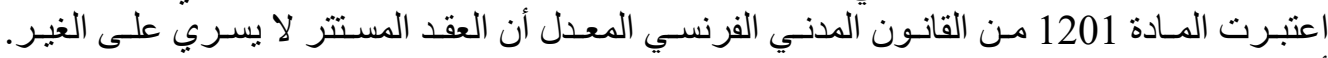

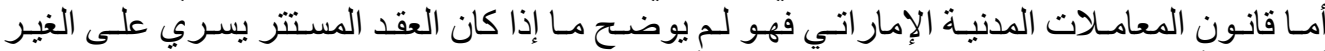

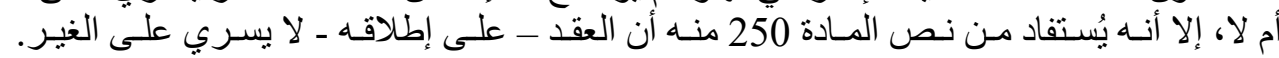

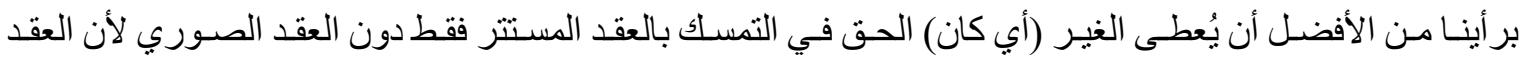

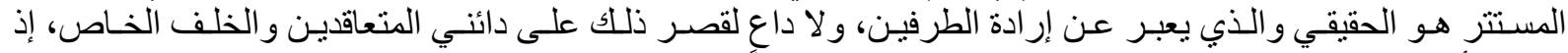

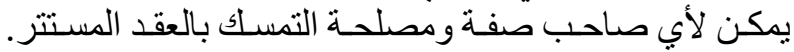

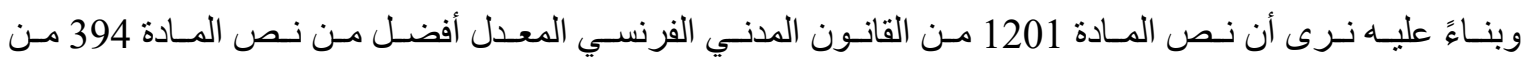

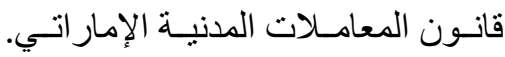

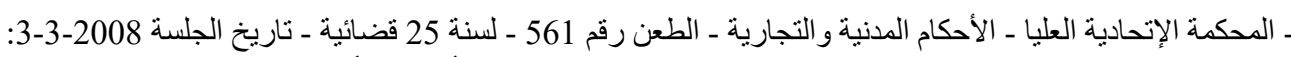

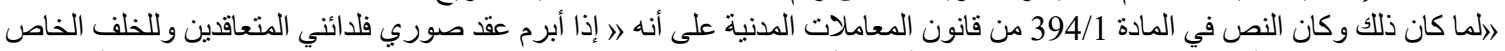

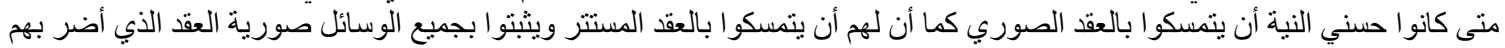
ـ محكمة التمبيز ـ الأحكام المدنية ـ الطعن رقم 48 ـ لسنة 2003 قضائية ـ تاريخ الجلسة 2005-2-13 ـ مكتب فني 16 - رقم الجزء 1 رقم الصفحة 297:

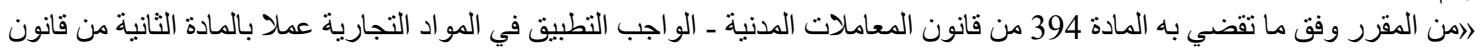

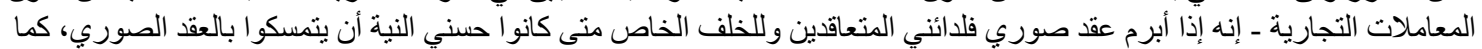

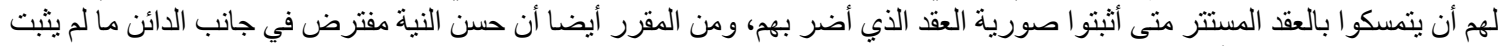

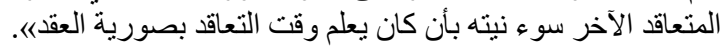




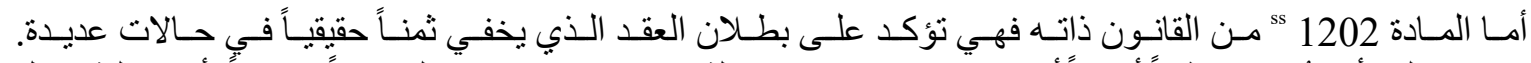

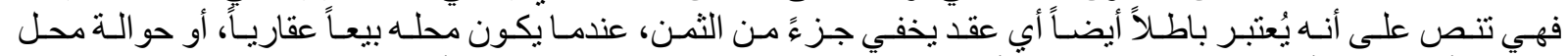

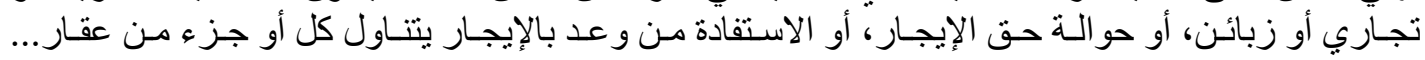
هذه المادة لا مثيل لها في قانون المعاملات المدنية الإمار اتي.

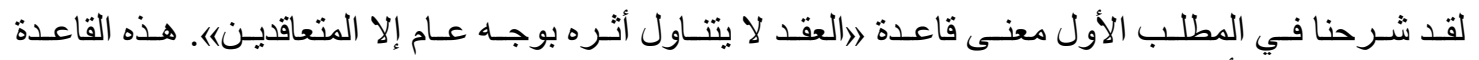

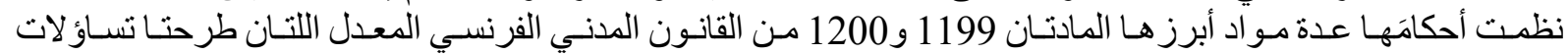

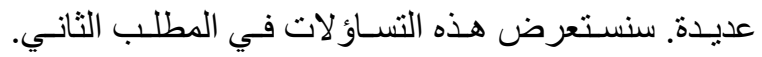

\title{
المطلب الثاني: تساؤلات تطرحها المادتان 1199 و1200 من القانون المدني الفرنسي المعدل
}

\author{
7. \\ على الر غـم مـن وضـوح المادتين 1199 و1200 مـن القانـون المدنـي الفرنسـي المعدل، لا بــــــن طـرح السـؤ الين \\ التاليين:

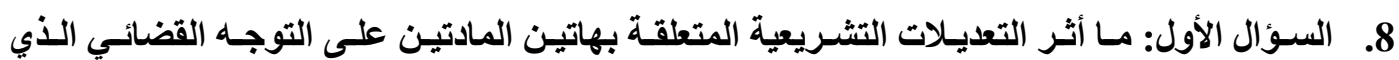

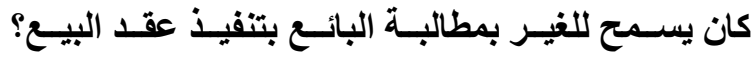

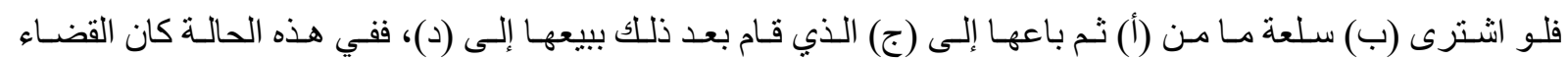

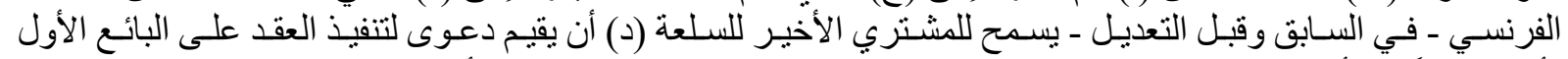

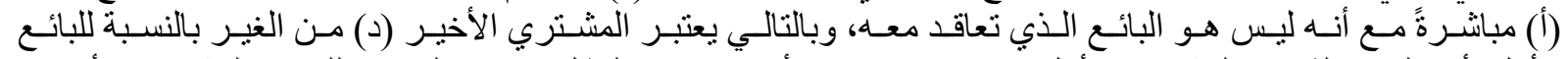

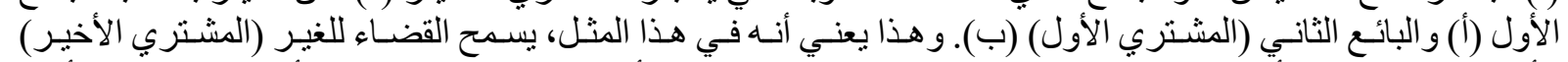

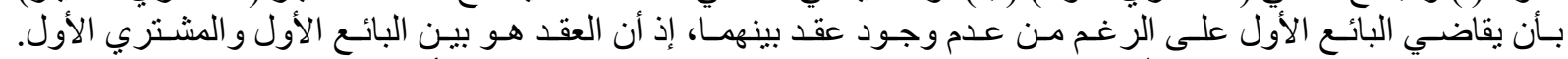

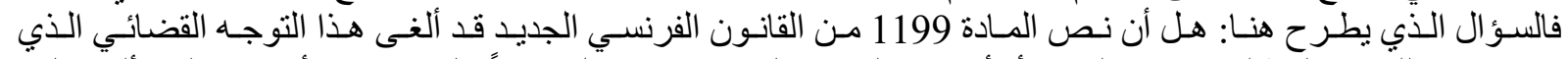

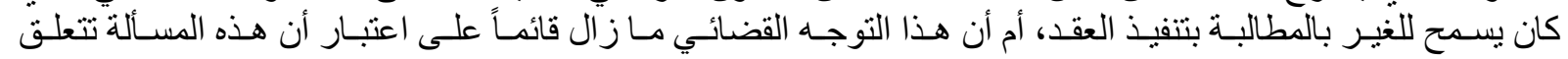

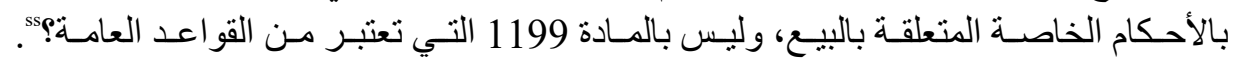

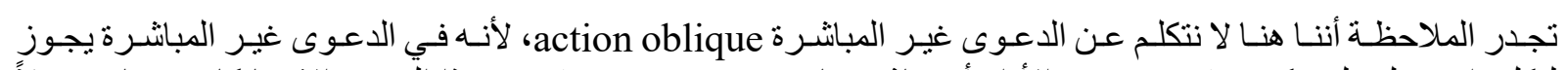

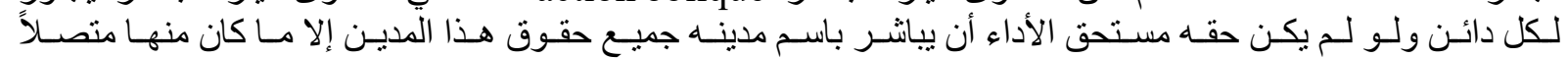

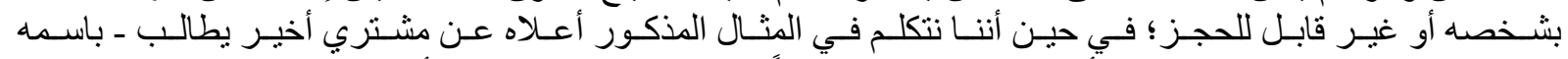

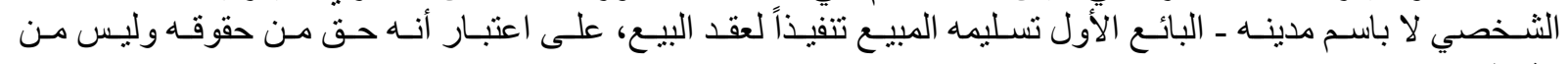
حقوق مدينهـ.

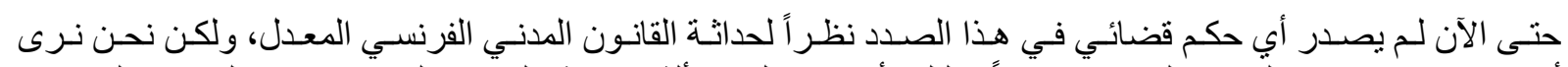

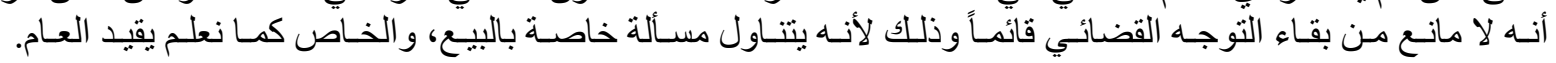

ss L'article 1202 (al. 2) de code civil réformé dispose que:

"Est également nul tout contrat ayant pour but de dissimuler une partie du prix, lorsqu'elle porte sur une vente d'immeubles, une cession de fonds de commerce ou de clientèle, une cession d'un droit à un bail, ou le bénéfice d'une promesse de bail portant sur tout ou partie d'un immeuble et tout ou partie de la soulte d'un échange ou d'un partage comprenant des biens immeubles, un fonds de commerce ou une clientèle".

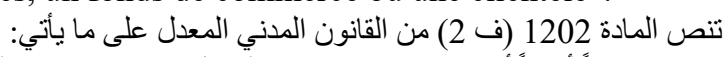

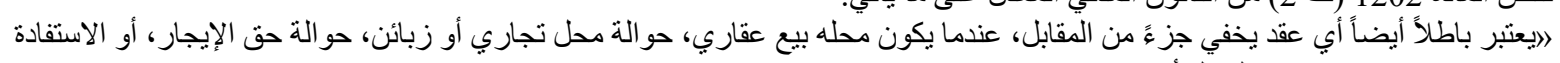

$$
\begin{aligned}
& \text { من وعد بالإيجار يتناول كل أو جزء من عن عقار ...《. }
\end{aligned}
$$

ss V. notamment G. Chantepie et M. Latina, La réforme du droit des obligations, commentaire théorique et pratique dans l'ordre du Code civil, n 549 . 


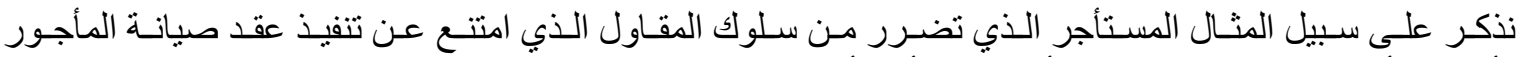

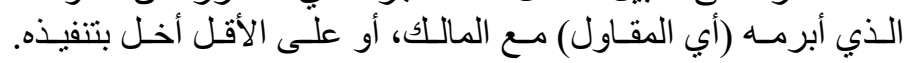

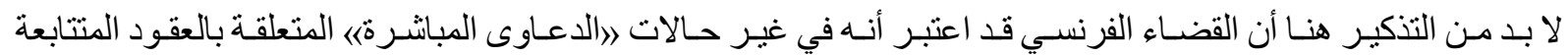

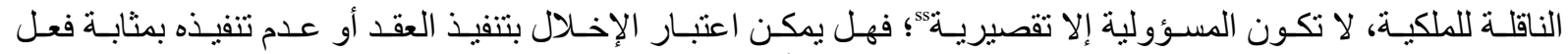

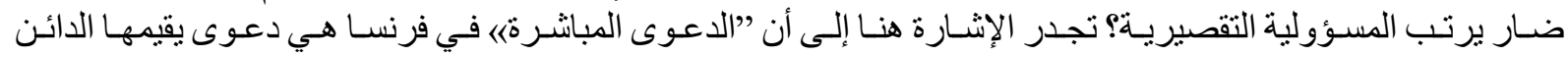

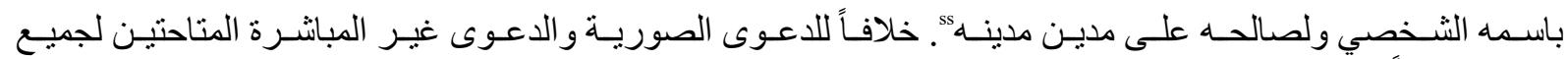

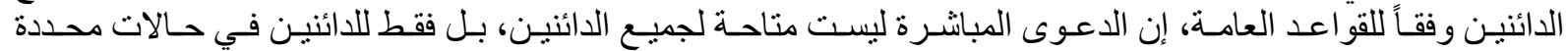

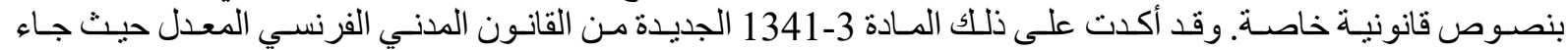

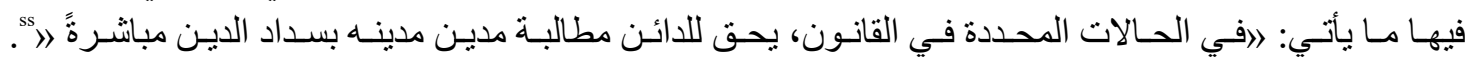

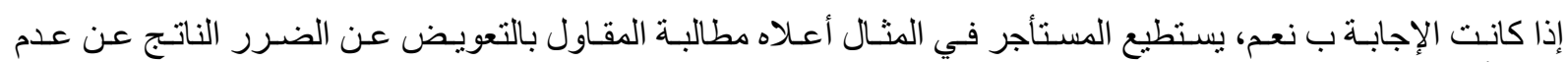

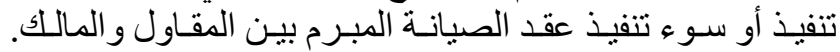

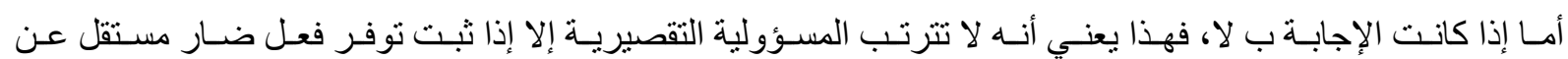
العقد.

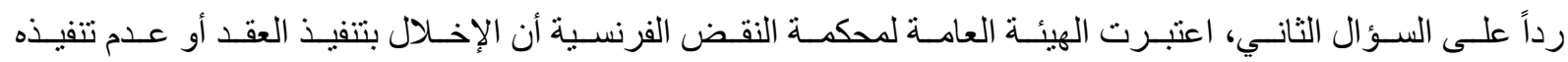

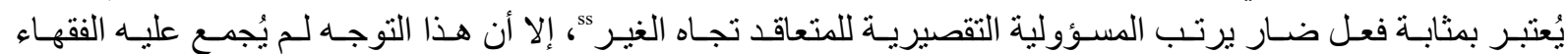

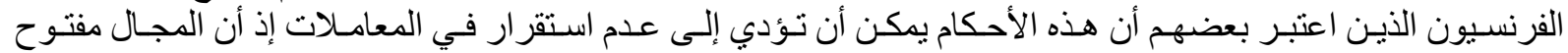

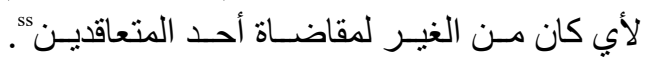

\section{رأي مشاريع القوانين المتعلقة بالقانون المدني الفرنسي حول هذه المسألة} انقسمت مشاريع القو انين المتعلقة بالقانون المدني الفرنسي إلى رأيين:

Catala امسودة مشروع كاتالاش》

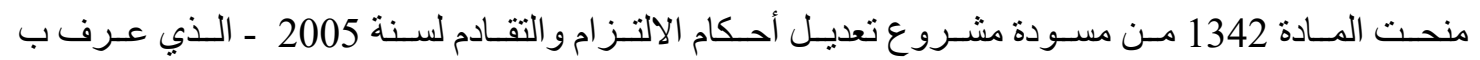

ss $\quad$ Ass. plén., 12 juill. 1991, D. 1991, p. 549, note J. Ghestin; Defrénois 1991, 1301, obs. J .-L. Aubert.

ss Jamin Ch., La notion d'action directe, préf. Ghestin J., LGDJ, 1991.

ss L'article 1341-3 du Code civil réformé rappelle que « dans les cas déterminés par la loi, le créancier peut agir directement en paiement de sa créance contre un débiteur de son débiteur ».

نذكر بعض النصوص الخاصة: فيما يخص الإيجار (المادة 1753 من القانون المدني)، والوكالة (المادة 1994 من القانئ المانون المدني)، و عقود المقاولة

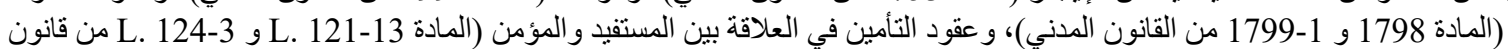

التأمين).

ss Cass. ass. plén., 6 oct. 2006, nº 05-13.255, Bull. civ. ass. plén., no 9, D. 2006, p. 2825, note Viney G., RLDC 2007/34, no 2346, note Brun Ph., RLDA 2006/11, n 656, note Jacques Ph., Resp. civ. et assur. 2006, étude 17, note Bloch L., JCP G 2006, II, n 10181, note Billiau M., JCP G 2007, I, n 115, obs. Stoffel-Munck Ph., JCP E 2007, 1000, note Auque F., RJDA 2007, nº 1, note Assie F. ; sur cet arrêt, voir également Mestre J., Une véritable théorie de la relativité, RLDC 2006/32, p. 3 :

" le tiers à un contrat peut invoquer, sur le fondement de la responsabilité délictuelle, un manquement contractuel dès lors que ce manquement lui a causé un dommage ".

״ يمكن اللغير المطالبة ـعلى أساس المسؤولية التقصيريةـ بتعويض عن التنفيذ الخاطئ للعقد والذي سبب له ضرراً .

V. cependant : Cass. Civ. $3^{\text {e }}$, 22 oct. 2008, Bull. civ. 111, 160 ; Cass. civ $1^{\text {re }}$, 15 déc. 2011, n. 10-17691.

ss Arnaud-Grossi I. et Mestre J., Les piliers du droit des sociétés pourront-ils résister longtemps à la responsabilité délictuelle pour simple manquement contractuel ?, RLDA 2008/24, n 1425. 


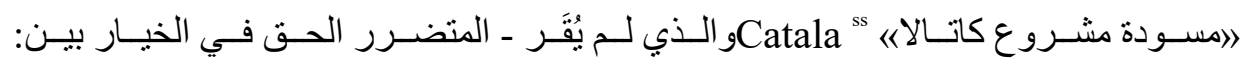

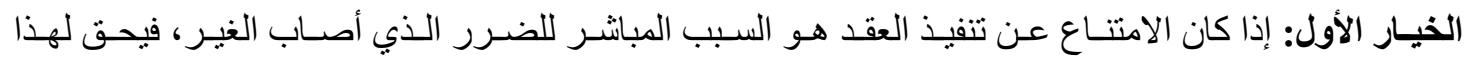

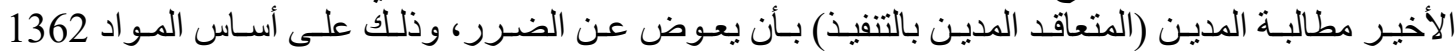

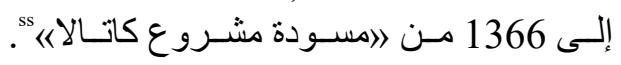

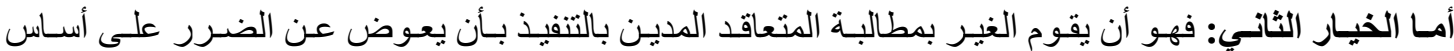

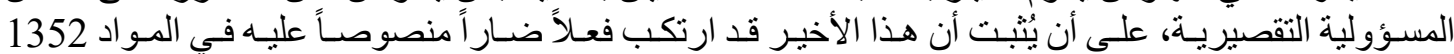

إلى 1362.

SS

$$
\text { و التصرفات الانفر ادية، و المسؤولية المدنية، و التنقادم. }
$$

ss Art. 1362 du projet Catala: "Sans préjudice de dispositions spéciales, l'exploitant d'une activité anormalement dangereuse, même licite, est tenu de réparer le dommage consécutif à cette activité.

Est réputée anormalement dangereuse l'activité qui crée un risque de dommages graves pouvant affecter un grand nombre de personnes simultanément.

L'exploitant ne peut s'exonérer qu'en établissant l'existence d'une faute de la victime dans les conditions prévues aux articles 1349 à 1351-1".

$$
\text { تنص المادة } 1362 \text { من مسودة مشروع كاتالا على ما يأتي: }
$$

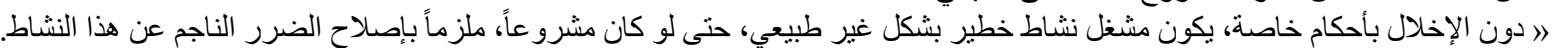

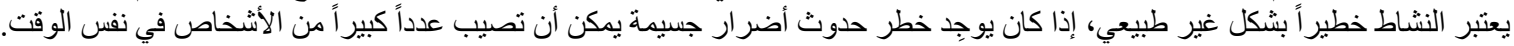

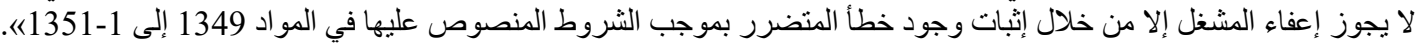

Art. 1363 du projet Catala: "Le créancier d'une obligation issue d'un contrat valablement formé peut, en cas d'inexécution, demander au débiteur réparation de son préjudice sur le fondement des dispositions de la présente section".

$$
\text { تتص المادة } 1363 \text { من مسودة مشروع كاتالا على ما يأتي: }
$$

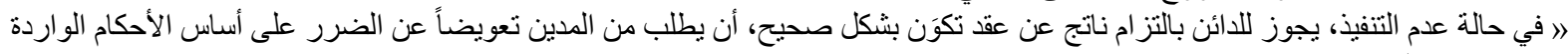

$$
\text { في هذا المبحث؛ }
$$

Art. 1364 du projet Catala: "Dans le cas où le débiteur s'oblige à procurer un résultat au sens de l'article 1149 , l'inexécution est établie du seul fait que le résultat n'est pas atteint, à moins que le débiteur ne justifie d'une cause étrangère au sens de l'article 1349.

Dans tous les autres cas, il ne doit réparation que s'il n'a pas effectué toutes les diligences nécessaires".

$$
\text { تنص المادة } 1364 \text { من مسودة مشروع كاتالا على ما يأتي: }
$$

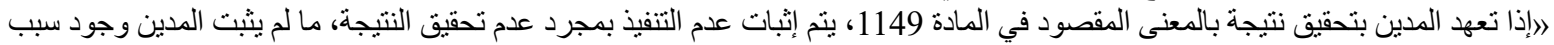

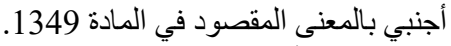

$$
\text { في جميع الحالات الأخرى، لا يلتزم بالتعويض المفاد إلا إذا لم يقم بكل العناية اللازمةها. }
$$

Art. 1365 du projet Catala: "La réparation du préjudice résultant du retard suppose la mise en demeure préalable du débiteur. La mise en demeure n'est requise pour la reparation de tout autre préjudice que lorsqu'elle est nécessaire pour caractériser l'inexécution".

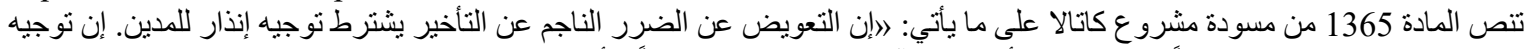

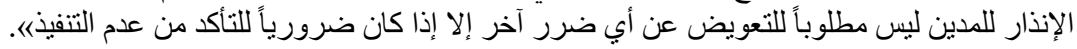

Art. 1366 du projet Catala: "Sauf dol ou faute lourde de sa part, le débiteur n'est tenu de réparer que les “conséquences de l'inexécution raisonnablement prévisibles lors de la formation du contrat

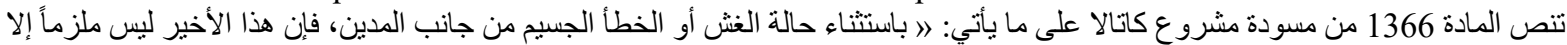

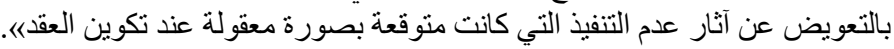

ss Art. 1352 du projet Catala: “Toute faute oblige son auteur à réparer le dommage qu'il a causé.

Constitue une faute la violation d'une règle de conduite imposée par une loi ou un règlement ou le manquement au devoir général de prudence ou de diligence.

Il n'y a pas de faute lorsque l'auteur se trouve dans l'une des situations prévues aux articles 122-4 à 122-7 du Code pénal".

$$
\text { تتص المادة } 1352 \text { من مسودة مشروع كاتالا على ما يأتي: }
$$

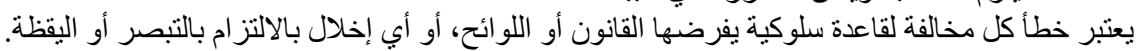

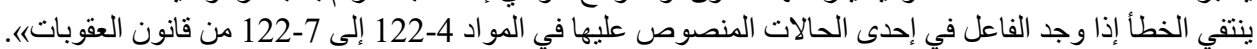

Art. 1353 du projet Catala: "La faute de la personne morale s'entend non seulement de celle qui est commise par un représentant, mais aussi de celle qui résulte d'un défaut d'organisation ou de fonctionnement". 
تنص المادة 1353 من مسودة مشروع كاتالا على ما ياتتي: 》 خطأ الثخص الاعتباري لبس فقط ذلك الذي يرتكبه ممثل عنه، ولكن أيضاً الخطأ

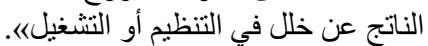

Art. 1354 du projet Catala: "On est responsable de plein droit des dommages causés par le fait des choses que l'on a sous sa garde".

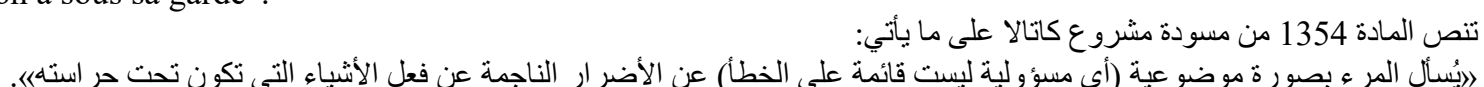

Art. 1354-1 du projet Catala: "Le fait de la chose est établi dès lors que celle-ci, en mouvement, est entrée en contact avec le siège du dommage.

Dans les autres cas, il appartient à la victime de prouver le fait de la chose, en établissant soit le vice de celle-ci, soit l'anormalité de sa position ou de son état".

$$
\begin{aligned}
& \text { تتص المادة 1354-1 من مسودة مشروع كاتالا على ما ياتتي: }
\end{aligned}
$$

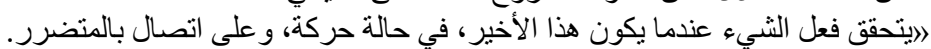

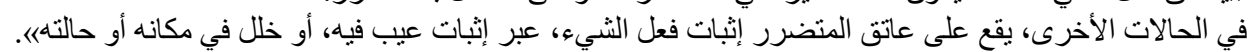

Art. 1354-2 du projet Catala: "Le gardien est celui qui a la maitrise de la chose au moment du fait dommageable. Le propriétaire est présumé gardien".

$$
\begin{aligned}
& \text { تتص المادة 2354-2 من مسودة مشروع كاتالا على ما ياتتي: }
\end{aligned}
$$

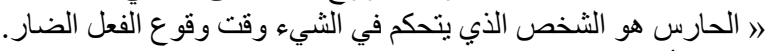

$$
\begin{aligned}
& \text { يُقتترض أن المالك هو الحارسبه. }
\end{aligned}
$$

Art. 1354-3 du projet Catala: "Ni le vice de la chose, ni le trouble physique du gardien ne constituent une cause d'exonération".

$$
\begin{aligned}
& \text { تتص المادة } 1363 \text { من مسودة مشروع كاتالا على ما يأتي: } \\
& \text { 》لا العيب في الثيء، و لا الاضطر اب الجسدي (الحالة الجسمانية المضطربة) للحارس، تثكل سبباً للإعفاء من المسؤولية)؛. }
\end{aligned}
$$

Art. 1354-4 du projet Catala: "Les articles 1354 à 1354-3 sont applicables aux dommages causés par les animaux".

$$
\text { تنص المادة 3-1354 من مسودة مشروع كاتالا على ما ياتتي: (اتطبق المواد } 1354 \text { إلى 3-1354 على الأضرار التي تسبيها الحيو انات)؛. }
$$

Art. 1355 du projet Catala: "On est responsable de plein droit des dommages causés par ceux dont on règle le mode de vie ou dont on organise, encadre ou contrôle l'activité dans son propre intérêt.

Cette responsabilité a lieu dans les cas et aux conditions prévues aux articles 1356 à 1360 . Elle suppose la preuve d'un fait de nature à engager la responsabilité de l'auteur direct du dommage".

$$
\begin{aligned}
& \text { تتص المادة } 1355 \text { من مسودة مشروع كاتالا على ما يأتي: } \\
& \text { 》ابسأل المرء مسؤولية موضو عية عن الاضضر ار التي يسبيها الأشخاص الذين يقوم هو بتنظيم أسلوب حياتهم، أو يقوم بتنظيم أو الإنشر اف أو التحكم }
\end{aligned}
$$

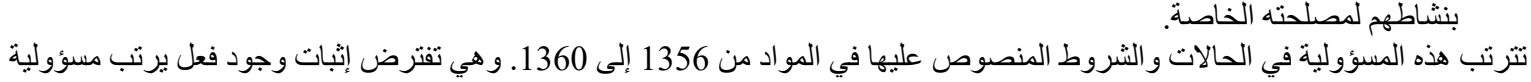

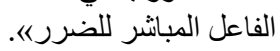

Art. 1356 du projet Catala: "Sont responsables des dommages causés par un enfant mineur :

- ses père et mère en tant qu'ils exercent l'autorité parentale;

- le tuteur en cas de décès de ceux-ci;

- la personne physique ou morale chargée par décision judiciaire ou administrative ou par convention, de régler le mode de vie du mineur. Cette responsabilité peut se cumuler avec celle des parents ou du tuteur".

$$
\begin{aligned}
& \text { تتص المادة } 1356 \text { من مسودة مشروع كاتالا على ما يأتي: }
\end{aligned}
$$

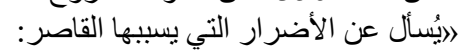

$$
\begin{aligned}
& \text { والده وأمه طالما يمارسان النسلطة الأبوية ؛ }
\end{aligned}
$$

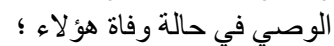

$$
\begin{aligned}
& \text { الثخص الطبيعي أو الاعتباري المكلف بموجب حكم قضائي أو إداري أو بموجب اتفاق، بتنظيم نمط حياة القاصر. يمكن الجمع بين هذه المسؤولية }
\end{aligned}
$$

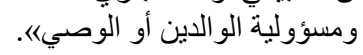

Art. 1357 du projet Catala: "Est responsable des dommages causés par un majeur dont l'état ou la situation nécessite une surveillance particulière la personne physique ou morale chargée, par décision judiciaire ou administrative ou par convention, de régler son mode de vie".

$$
\begin{aligned}
& \text { تنص المادة } 1357 \text { من مسودة مشرو ع كاتالا على ما يأتي: }
\end{aligned}
$$

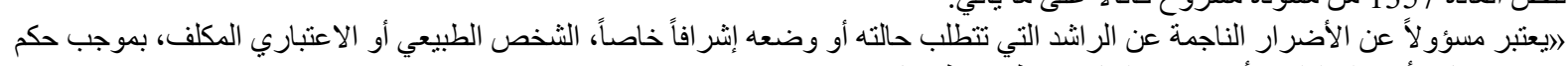

$$
\begin{aligned}
& \text { قضائي أو قرار إداري أو بموجب الثفاق، بتنظيخ نمط حياتهاه. }
\end{aligned}
$$

Art. 1358 du projet Catala: "Les autres personnes qui assument, à titre professionnel, une mission de surveillance d'autrui, répondent du fait de l'auteur direct du dommage, à moins qu'elles ne démontrent qu'elles n'ont pas commis de faute".

$$
\begin{aligned}
& \text { تتص المادة } 1358 \text { من مسودة مشرو ع كاتالا على ما ياتي: } \\
& \text { ״عتبر الأشخاص الآخرون الذين يتولون، بصفتهم المهنية، مهمة مر اقبة الغير، مسؤولين عن فعل الغير ، ما لم يثبتوا أنهم لم برتكبو ا خطأ). }
\end{aligned}
$$




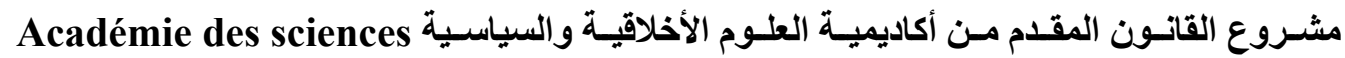

\section{(ASMP) morales et politiques}

\author{
Académie des sciences mo- اعتبر مشـروع القانـون المقدم مـن أكاديميـة العلـوم الأخلاقيـة والسياسـية
}

Art. 1359 du projet Catala: "Le commettant est responsable des dommages causés par son préposé.

Est commettant celui qui a le pouvoir de donner des ordres ou des instructions en relation avec l'accomplissement des fonctions du préposé.

Le commettant n'est pas responsable s'il prouve que le préposé a agi hors des fonctions auxquelles il était employé, sans autorisation et à des fins étrangères à ses attributions. Il ne l'est pas davantage s'il établit que la victime ne pouvait légitimement croire que le préposé agissait pour le compte du commettant".

$$
\begin{aligned}
& \text { تتص المادة } 1359 \text { من مسودة مشرو ع كاتالا على ما يأتي: }
\end{aligned}
$$

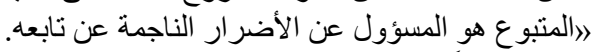

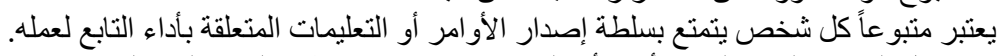

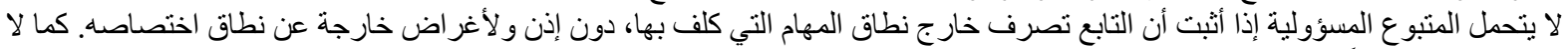

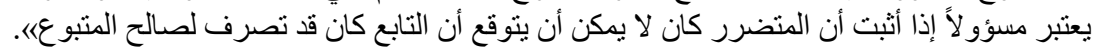

Art. 1359-1 du projet Catala: "Le préposé qui, sans commettre une faute intentionnelle, a agi dans le cadre de ses fonctions, à des fins conformes à ses attributions et sans enfreindre les ordres de son commettant ne peut voir sa responsabilité personnelle engagée par la victime qu'à condition pour celle-ci de prouver qu'elle n'a pu obtenir du commettant ni de son assureur réparation de son dommage ".

$$
\text { تنص المادة 1359-135 من مسودة مشروع كاتالا على ما يأتي: }
$$

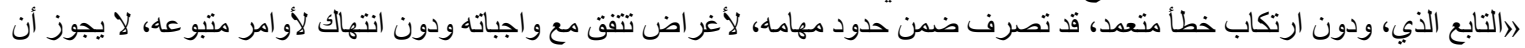

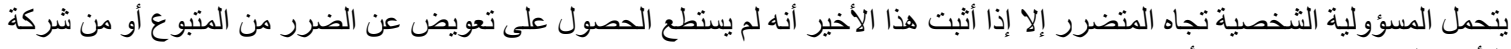

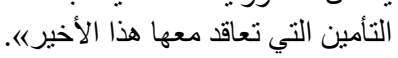

Art. 1360 du projet Catala: "En l'absence de lien de préposition, celui qui encadre ou organise l'activité professionnelle d'une autre personne et en tire un avantage économique est responsable des dommages causés par celle-ci dans l'exercice de cette activité. Il en est ainsi notamment des établissements de soins pour les dommages causés par les médecins qu'ils emploient. Il appartient au demandeur d'établir que le fait dommageable résulte de l'activité considérée.

De même, est responsable celui qui contrôle l'activité économique ou patrimoniale d'un professionnel en situation de dépendance, bien qu'agissant pour son propre compte, lorsque la victime établit que le fait dommageable est en relation avec l'exercice du contrôle. Il en est ainsi notamment des sociétés mères pour les dommages causés par leurs filiales ou des concédants pour les dommages causés par leurs concessionnaires".

$$
\begin{aligned}
& \text { تنص المادة } 1360 \text { من مسودة مشروع كاتالا على ما ياتتي: }
\end{aligned}
$$

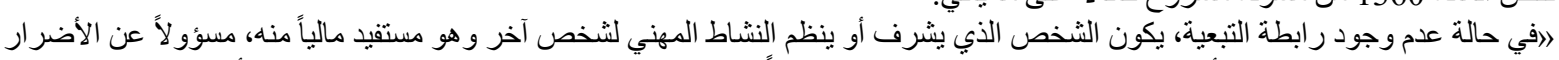

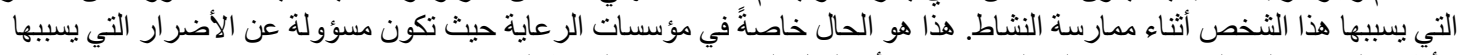

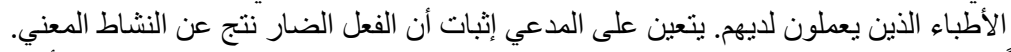

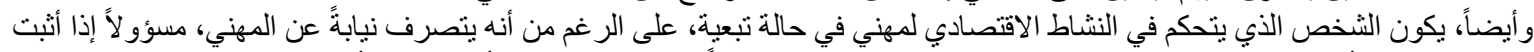

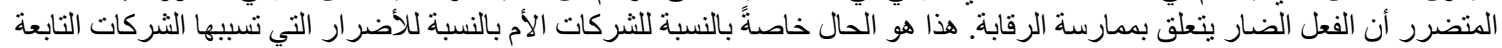

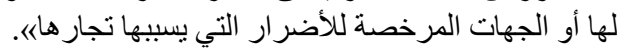

Art. 1361 du projet Catala: "Le propriétaire, le détenteur ou l'exploitant d'un fonds, qui provoque un trouble excédant les inconvénients normaux du voisinage, est de plein droit responsable des conséquences de ce trouble".

$$
\begin{aligned}
& \text { تتص المادة } 1361 \text { من مسودة مشروع كاتالا على ما يأتي: }
\end{aligned}
$$

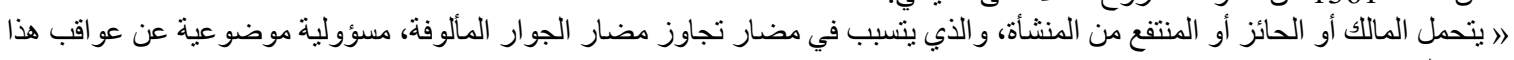

$$
\begin{aligned}
& \text { المضار 《. }
\end{aligned}
$$

Art. 1362 du projet Catala: "Sans préjudice de dispositions spéciales, l'exploitant d'une activité anormalement dangereuse, même licite, est tenu de réparer le dommage consécutif à cette activité.

Est réputée anormalement dangereuse l'activité qui crée un risque de dommages graves pouvant affecter un grand nombre de personnes simultanément.

L'exploitant ne peut s'exonérer qu'en établissant l'existence d'une faute de la victime dans les conditions prévues aux articles 1349 à 1351-1".

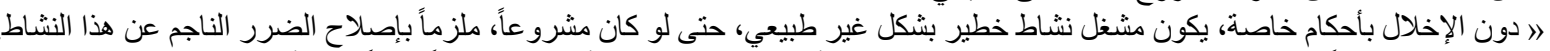

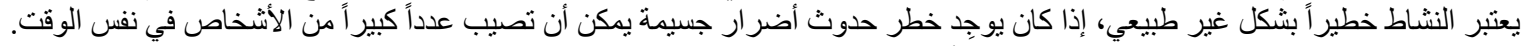

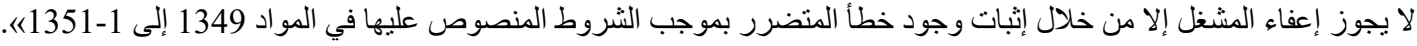


أن (ASMP) rales et politiques

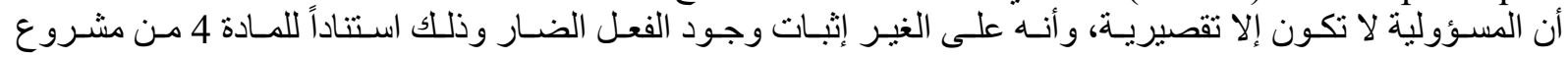

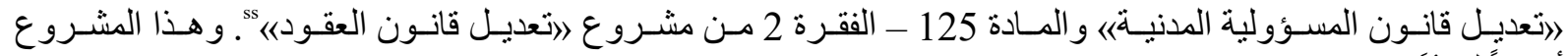

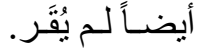

$$
\text { رأي القانون المدني الفرنسي المعدل }
$$

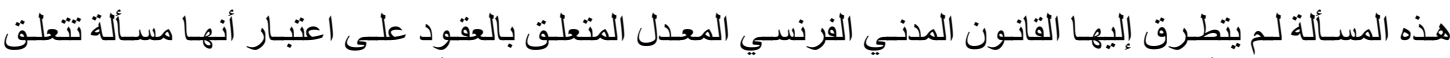

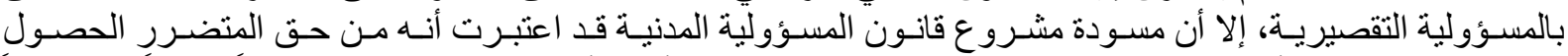

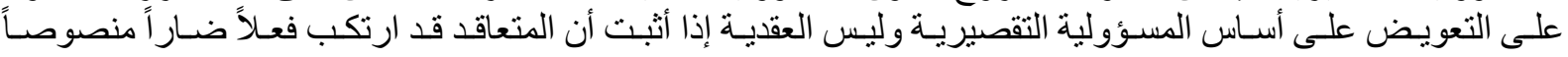

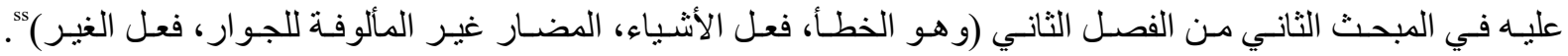

\section{رأي قانون المعاملات المدنية الإماراتي}

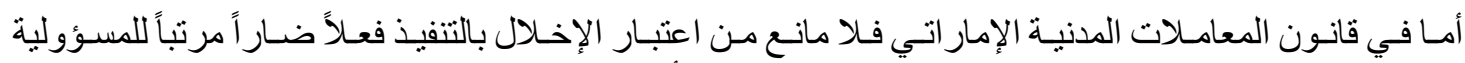

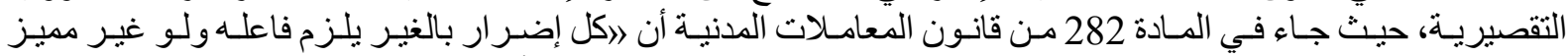

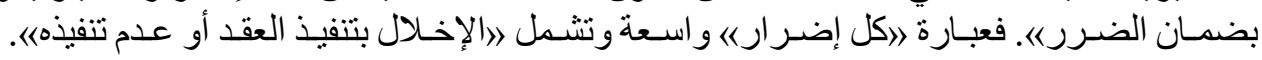

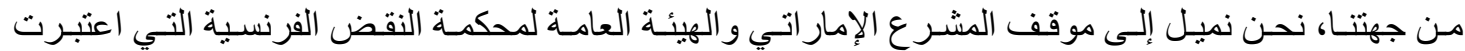

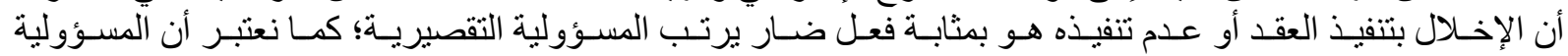

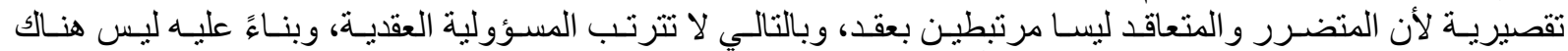

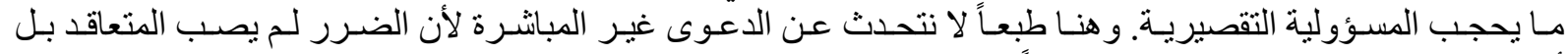

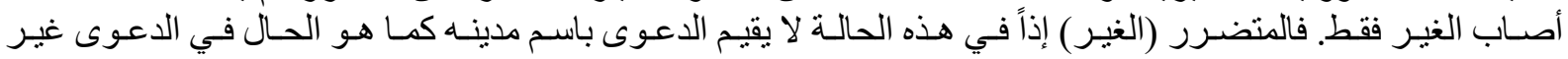

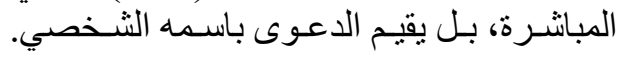

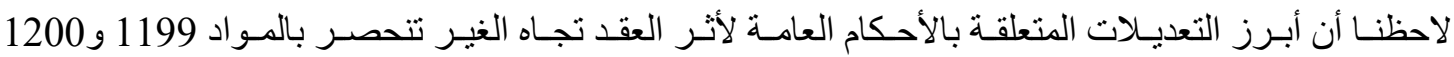

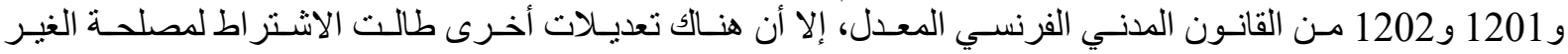
و التعهد عن الغيـر.

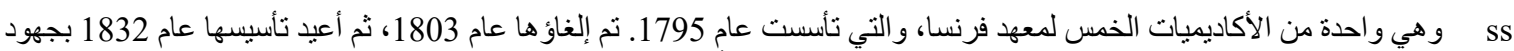

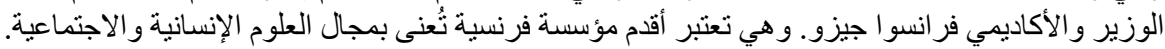

ss L'article 4 dispose que "Sous réserve des dispositions de l'article 3, l'inexécution préjudiciable d'un contrat ne donne lieu à dommages-intérêts qu' aux conditions et dans la mesure prévues par les articles 1146 et suivants du code civil ".

تتص المادة 4 من مشروع 》اتعديل قانون المسؤولية المدنية)، المقدم من أكاديمية العلوم الأخلاقية والسياسية على ما يأتي:

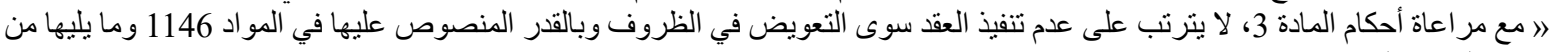
القانون المدني《.

ss Art. 1234 : «Lorsque l'inexécution d'une obligation contractuelle est la cause directe d'un dommage subi par un tiers, celui-ci ne peut en demander réparation au débiteur que sur le fondement de la responsabilité extracontractuelle, à charge pour lui de rapporter la preuve de l'un des faits générateurs visés à la section II du chapitre II ».

تنص المادة 1234 على ما يأني:

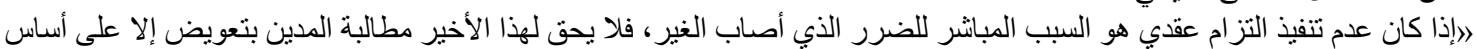

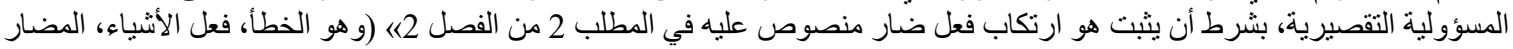
غير المألوفة للجوار، فعل الغير). 


\title{
المبحث الثاني: الاشتراط لمصلحة الغير Stipulation pour autrui والتعهد عن الغير Porte-fort
}

\author{
10.

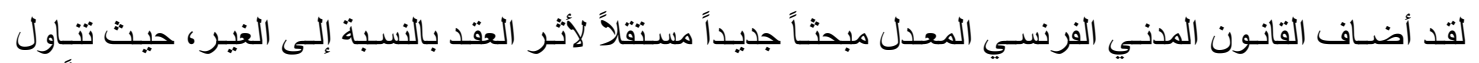

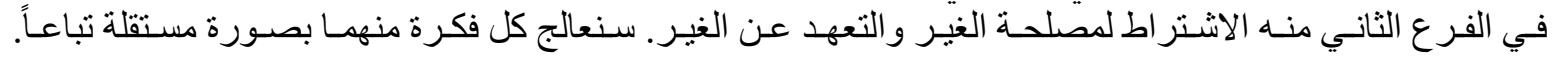

Stipulation pour autrui المطلب الأول: الاشتراط لمصلحة الغير

\section{1. تعريف الاشتراط لمصلحة الغير وشروطه}

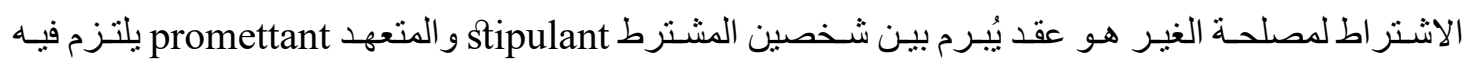

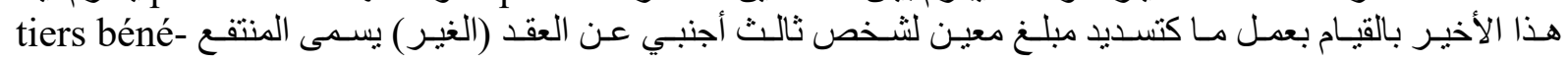

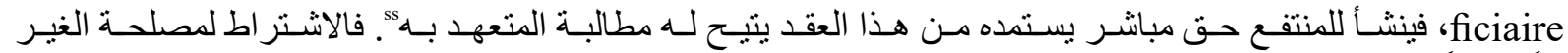

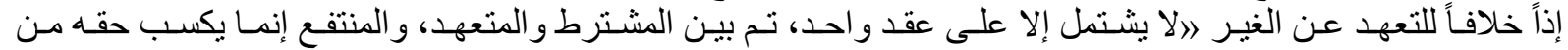

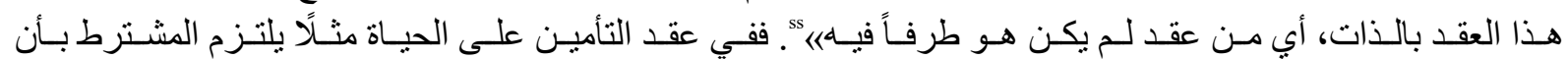

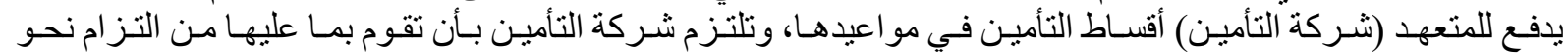
الورثـة في حسال وفـاة المشترطن.

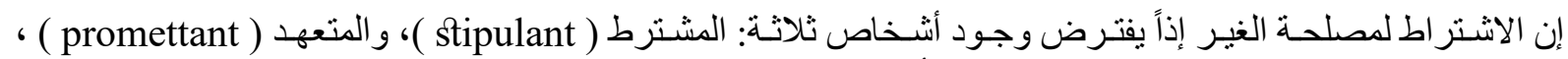

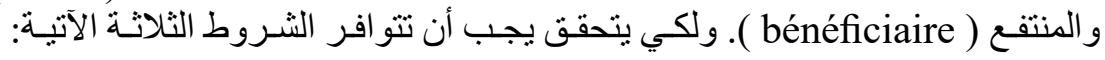

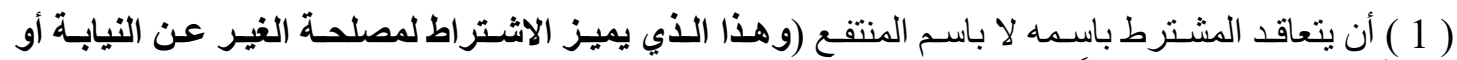

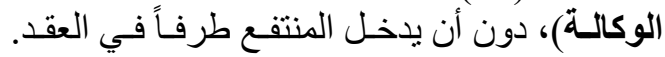

(2 ) أن يشترط المشترط على المتعهد حقاً مباشر اً للمنتفع.

( 3 ) أن يكون للمشترط من ور اء هذا الاشتر اط مصلحة شخصية، مادية كانت أو أدبية، و إلا كان فضولياً.

12 ـاستحداث مواد قانونية جديدة تنظم 》الاشتر اط لمصلحة الغير)

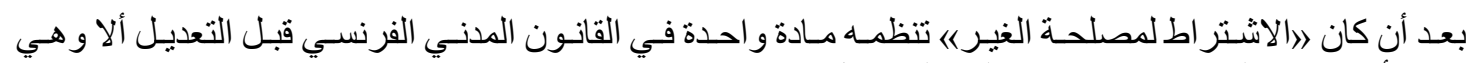

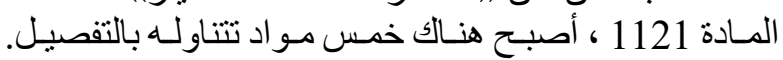

الوضع في ظل القانون المدني الفرنسي قبل تعديله

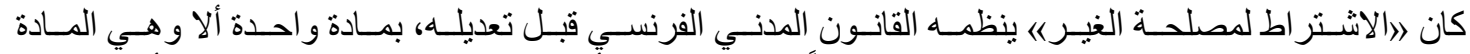

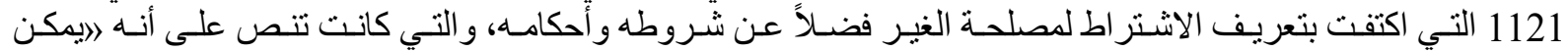

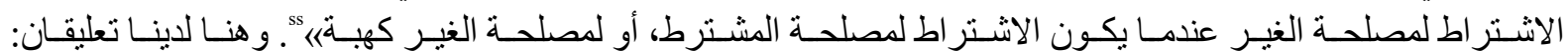

ss Cass. com., 7 oct. 1997, nº 95-18.119, Bull. civ. IV, n²51, RJDA 1997, nº 1498, JCP G 1998, I, no 131 , note Caussain J.-J. et Viandier A., RTD civ. 1998, p. 902, obs. Mestre J., Bull. Joly Sociétés 1997, p. 1058, note Mousseron P., D. 1998, p. 112, note Delebecque Ph.

SS

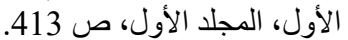

ss L'article 1121 de Code civil avant la réforme dispose que:

'On peut pareillement stipuler au profit d'un tiers lorsque telle est la condition d'une stipulation que l'on fait 


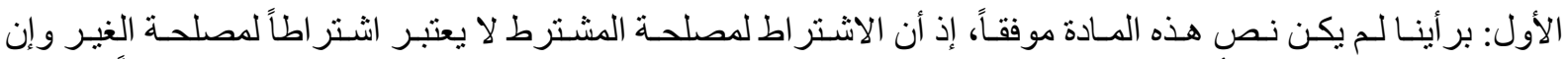

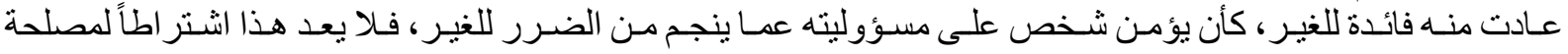

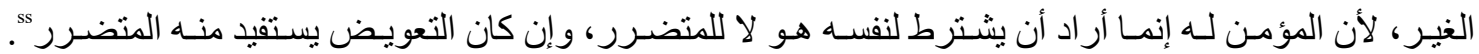

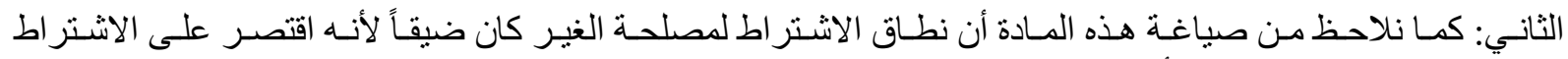

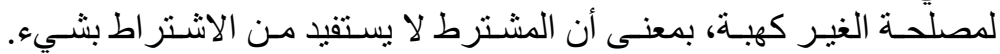

\section{تكريس 》الاشتراط لمصلحة الغير) كمبدأ}

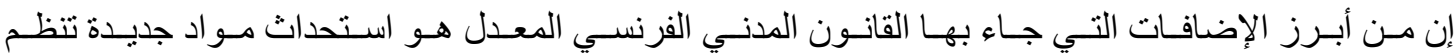

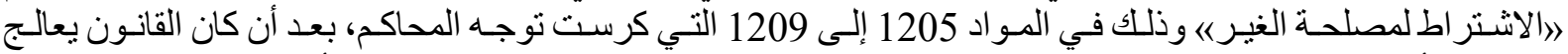

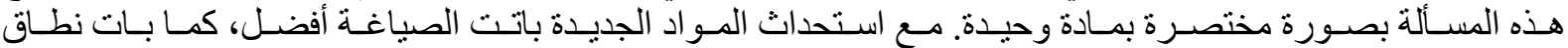

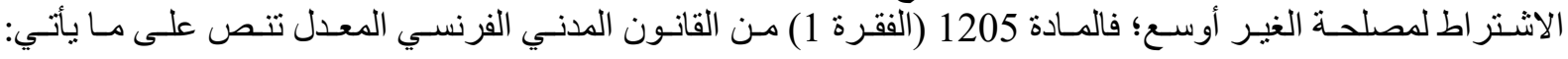

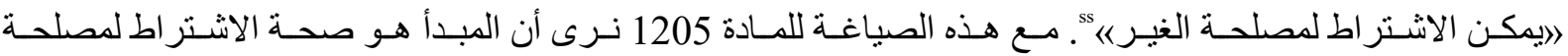

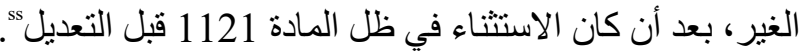

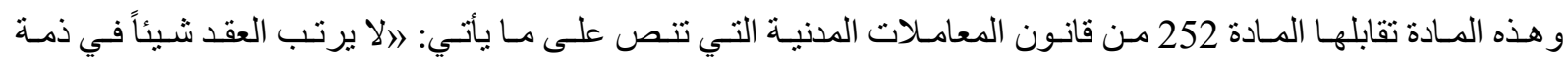

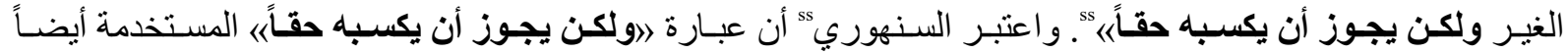

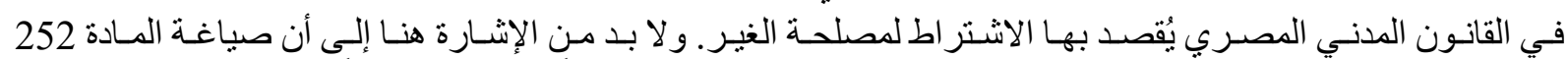

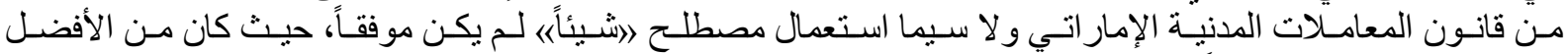

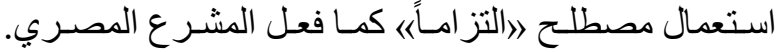
وقد أكد القضاء الإمار اتي على هذا المبدأ في أحكام عدة معتبر اً ما يأتي:

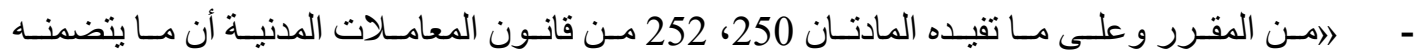

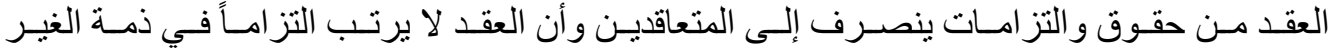
ولكن يجـوز أن يكسـبه حقــاً،.

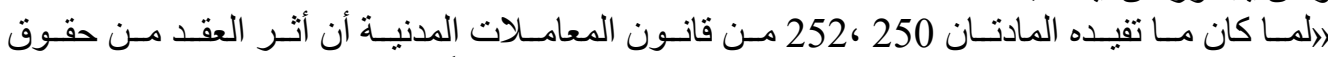

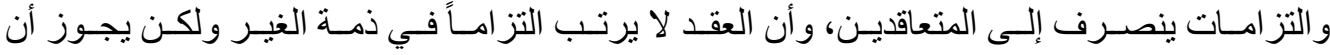

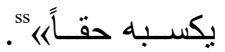

pour soi-même ou d'une donation que l'on fait à un autre".

تتص المادة 1121 من القانون الددني قبل التعديل على ما باتتي:

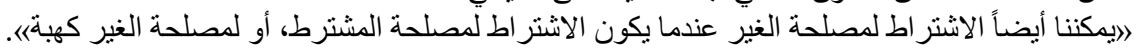

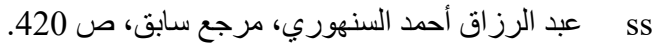

ss L'article 1205 (alinéa 1) du Code civil dispose que:

"On peut stipuler pour autrui".

$$
\text { تنص المادة } 1205 \text { (الفقرة الأولى) من القانون المدني على ما يأتي: }
$$

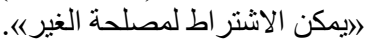

ss $\quad$ Terré Fr., Simler Ph. et Lequette Y., Droit civil. Les obligations, Dalloz, 11e éd., 2013, n 516.

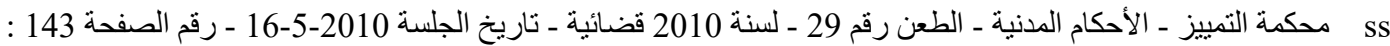

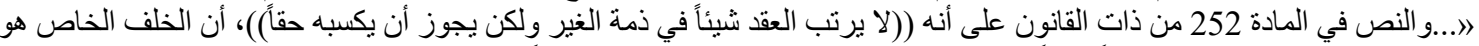

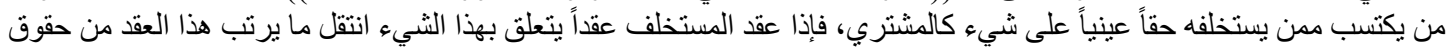

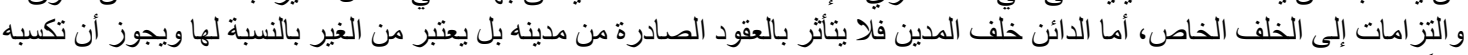
حقاً؛.

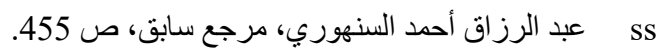

محكمة التمييز ـ الأحكام الدنية ـ الطعن رقم 302 ـ لسنة 2007 قضائية ـ تاريخ الجلسة 2008-2-3 - مكتب فني 19 - رقم الجزء 1 رقم الصفحة 264.

ss المحكمة الإتحادية العليا ـ الأحكام الدنية والتجارية ـ الطعن رقم 378 ـ لسنة 28 قضائية ـ تاريخ الجلسة 2007-4-24 - مكتب فني 29 رقم الصفحة 347. 


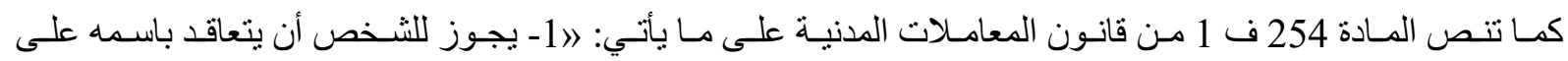

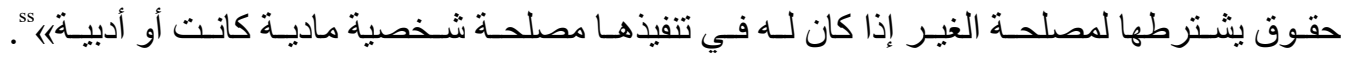

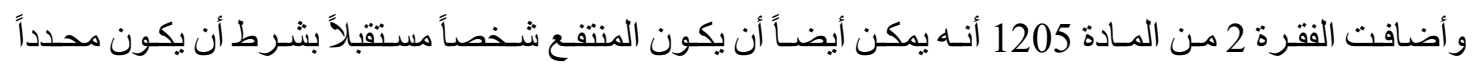

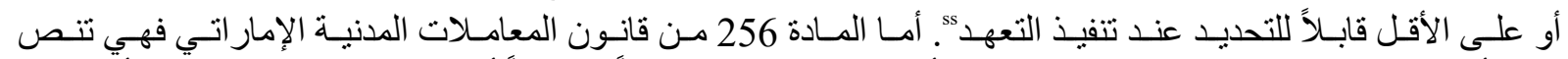

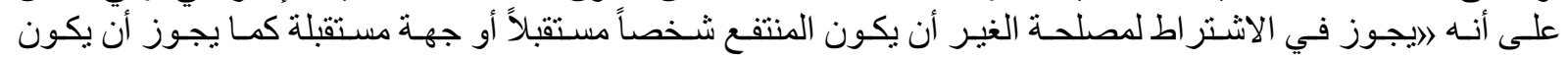

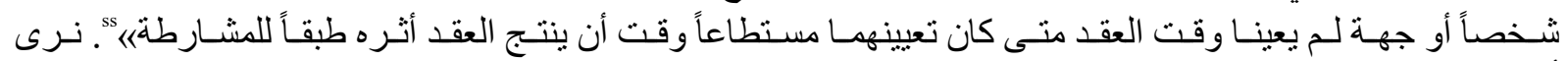

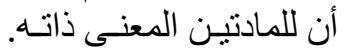

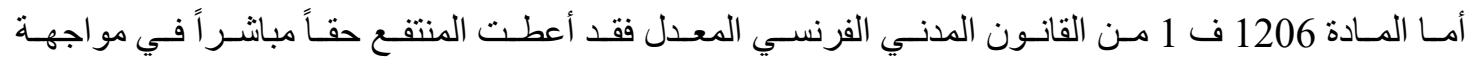

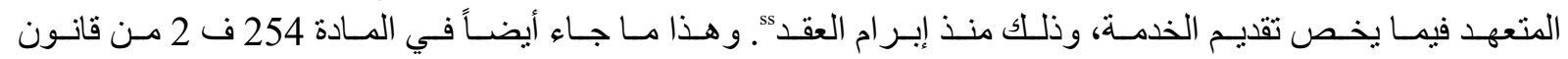

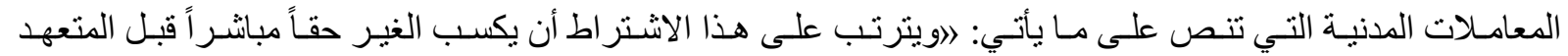

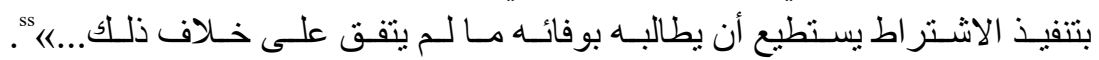

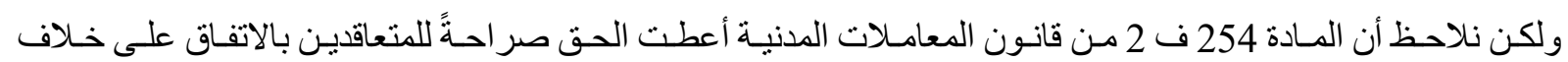

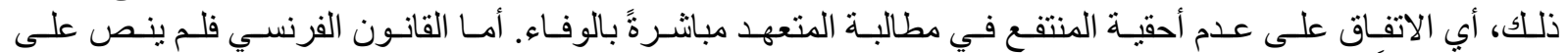

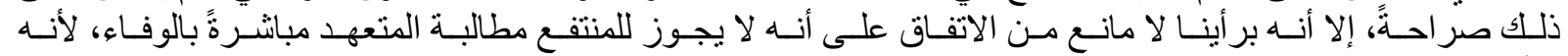

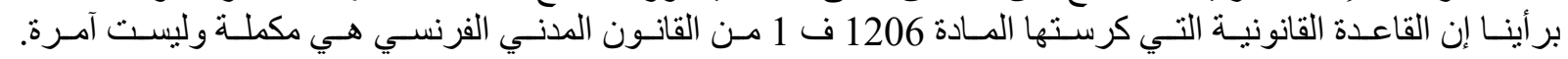

\section{الرجوع عن الاشتراط لمصلحة الغير}

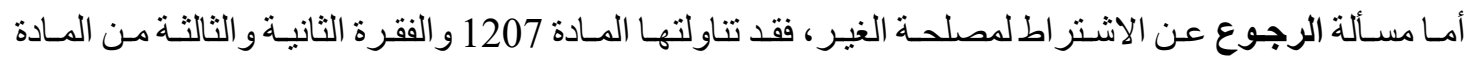

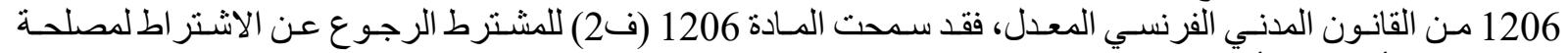

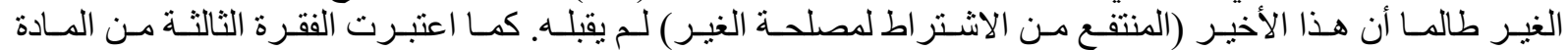

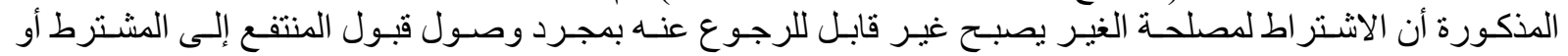

SS

$$
2 \text { - رقم الصفحة 1247: }
$$

》ا مؤدى ـ نص المادة (254) من القانون آنف الذكر ـ أنه في الاشتر اط لمصلحة الغير يتعاقد المشترط مع المتعهد باسمه على حقوق يشترطها

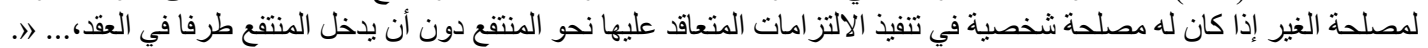

ss L'article 1205 (al. 2) de code civil réformé dispose :

'L'un des contractants, le stipulant, peut faire promettre à l'autre, le promettant, d'accomplir une prestation au profit d'un tiers, le bénéficiaire. Ce dernier peut être une personne future mais doit être précisément désigné ou pouvoir être déterminé lors de l'exécution de la promesse".

$$
\text { تنص المادة } 1205 \text { (الفقرة الثانية) من القانون المدني المعدل على ما يأتي: }
$$

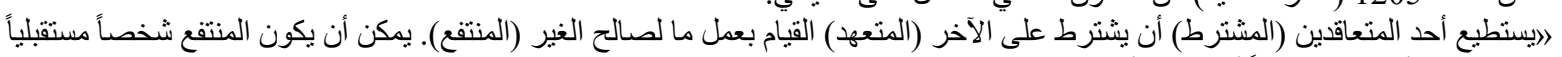
بشرط أن يكون محدداً أو على الأقل قابل للتحديد عند تنفيذ التعهدها.

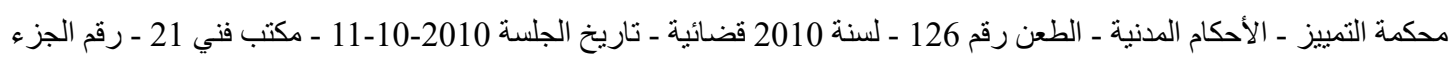

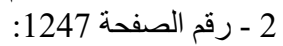

》 .... و أن المنتفع إنما يكسب حقه مباشرة من العقد ذاته المبرم بين المشترط و المتعهد بأن تشترط الحقوق لصالحه باعتباره منتفعا فيه ويجري

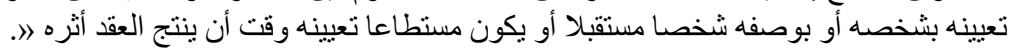

: L'article 1206 (alinéa 1) de code civil réformé dispose ss . « Le bénéficiaire est investi d`un droit direct à la prestation contre le promettant dès la stipulation » تتص المادة 1206 من القانون المدني المعدل على ما يأتي:

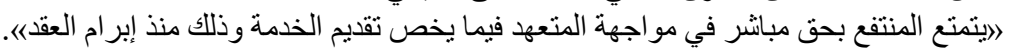

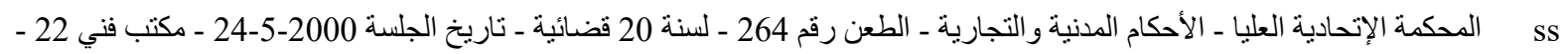

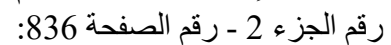

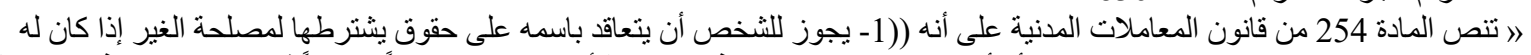

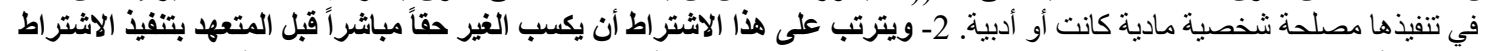

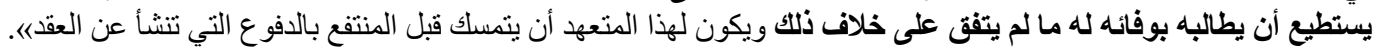




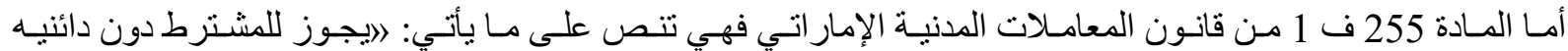

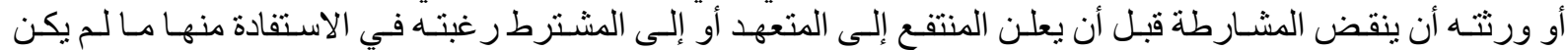

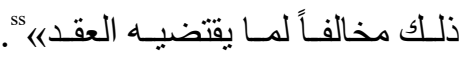

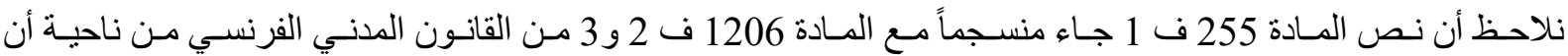

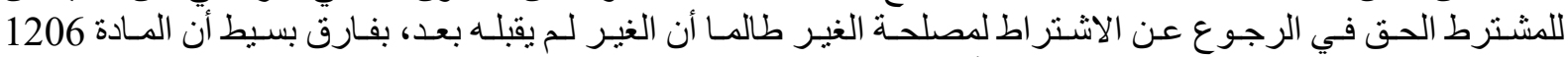

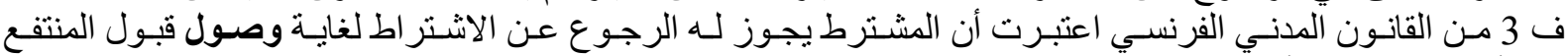

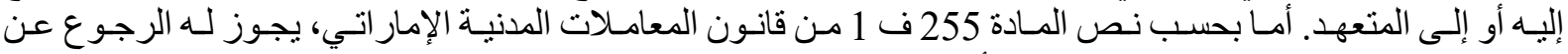

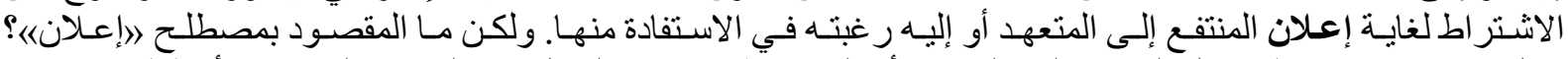

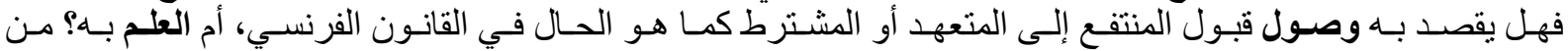

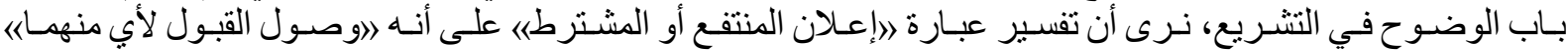
أ فضل.

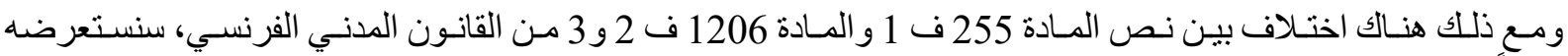
وفقـاً للآتي:

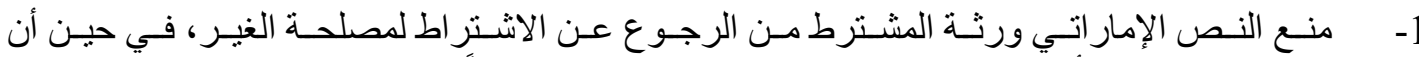

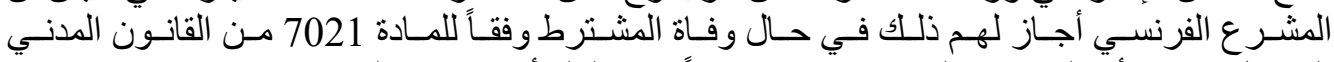

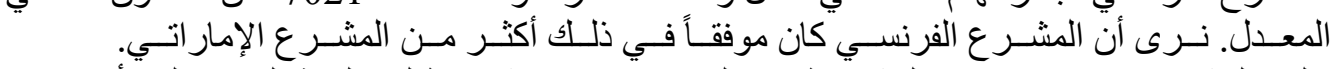

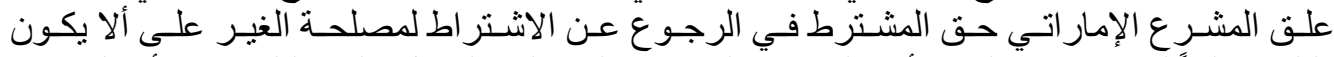

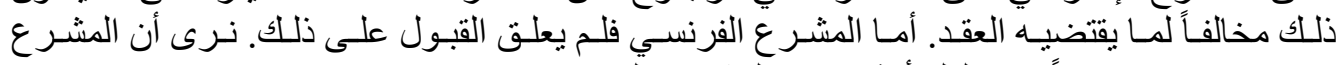

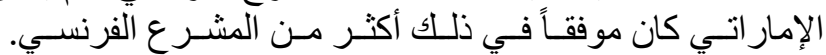

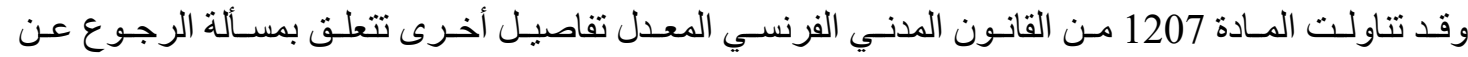

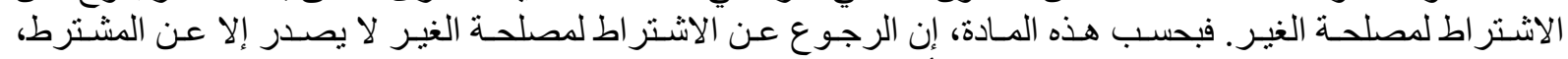

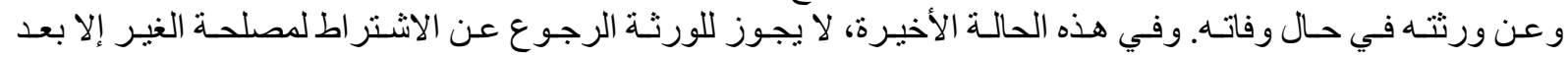

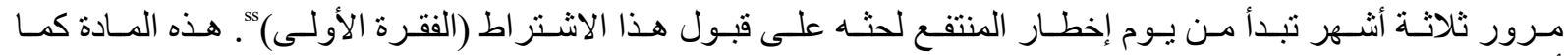

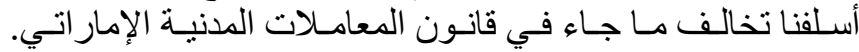

ss L'article 1206 (alinéa 2 et 3 ) de code civil réformé dispose :

« Le bénéficiaire est investi d`un droit direct à la prestation contre le promettant dès la stipulation. Néanmoins le stipulant peut librement révoquer la stipulation tant que le bénéficiaire ne l’a pas acceptée. La stipulation devient irrévocable au moment où l'acceptation parvient au stipulant ou au promettant ».

تتص المادة 1206 (ف 2 و 3) من القانون المدني المعدل على ما يأتي:

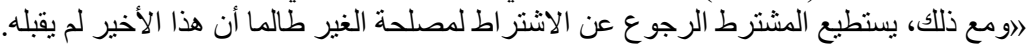

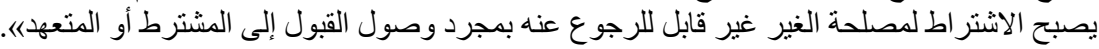

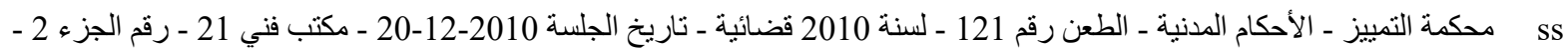

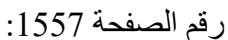

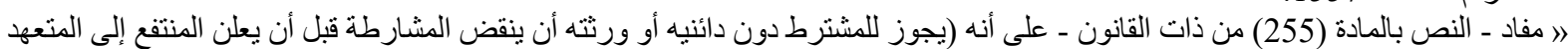

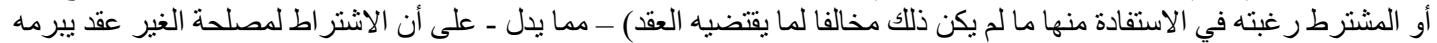

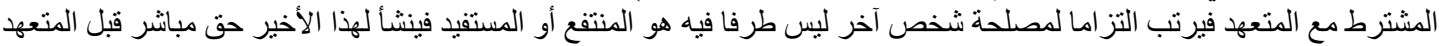

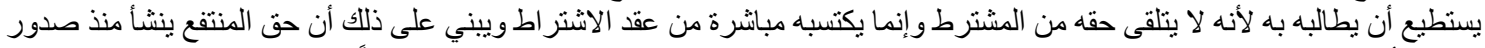

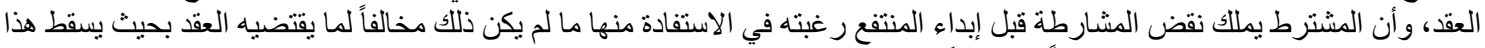

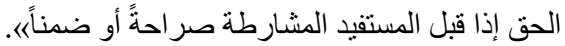

ss L'article 1207 (alinéa 1) de code civil réformé dispose :

«La révocation ne peut émaner que du stipulant ou, après son décès, de ses héritiers. Ces derniers ne peuvent y procéder qu'à l'expiration d'un délai de trois mois à compter du jour où ils ont mis le bénéficiaire en demeure de l'accepter $»$.

$$
\text { تنص المادة } 1207 \text { (الفقرة الأولى) من القانون الدذني المعدل على ما ياتتي: }
$$

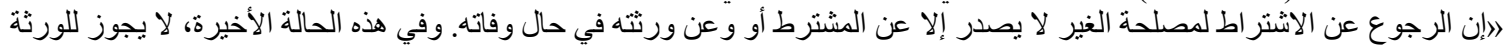

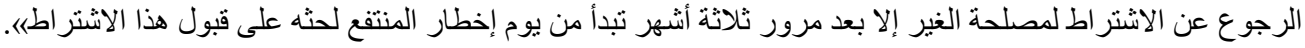




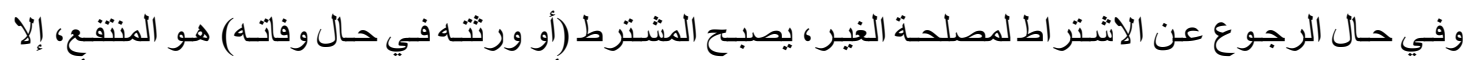

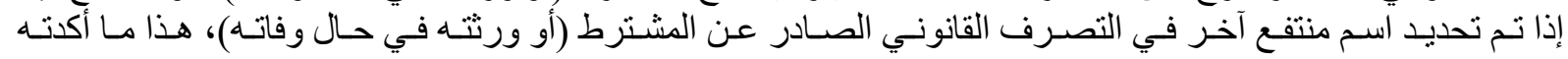

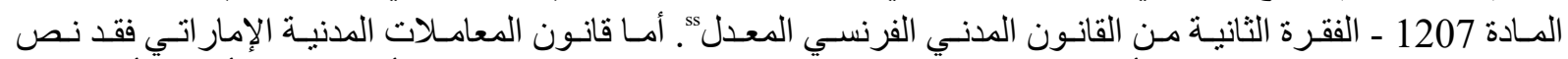

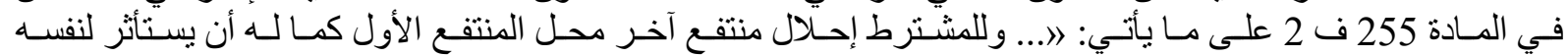

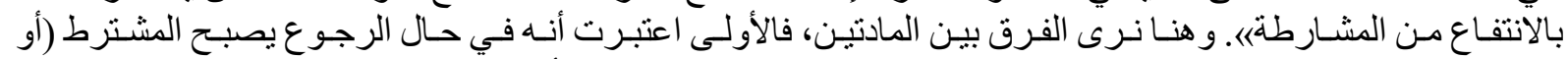

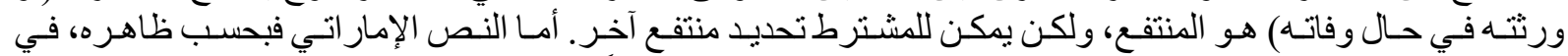

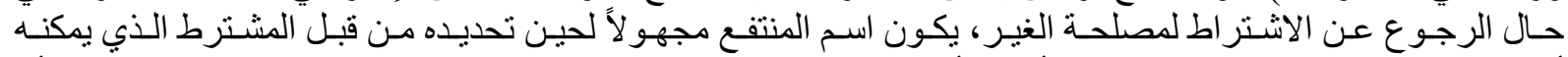

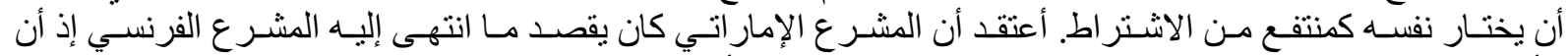

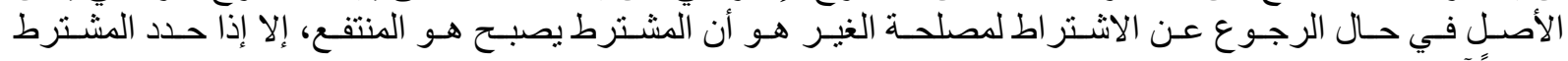
منتفعـاً آخر.

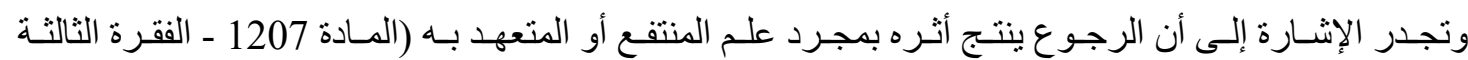

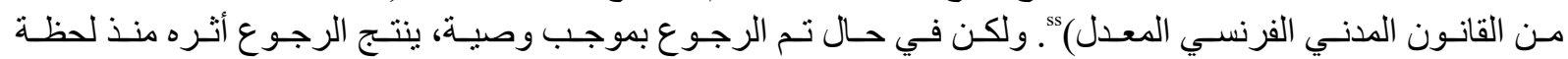

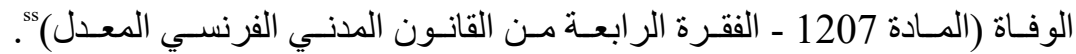

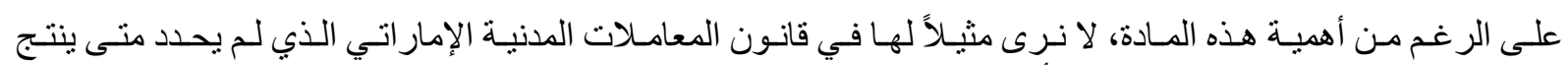

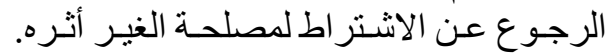

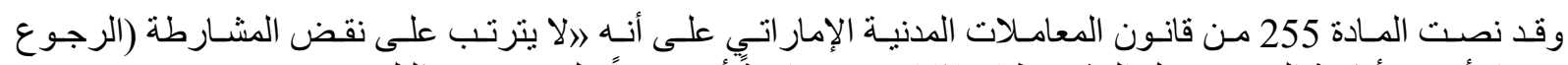

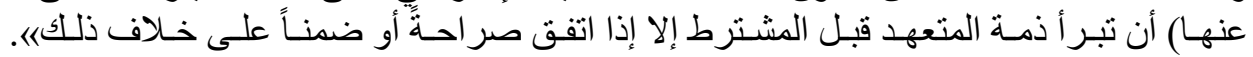

قبول الاشتر اط لمصلحة الغير وتنفيذه

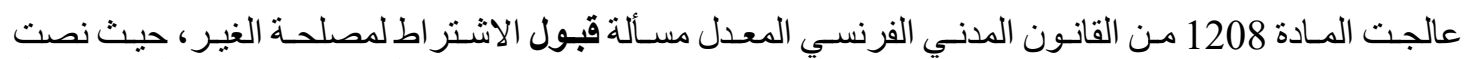

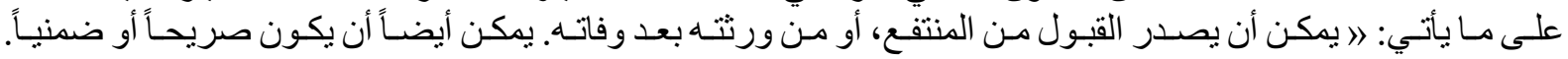

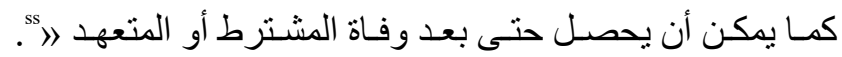

هذه المادة أيضاً لا مثيل لها في قانون المعاملات المدنية الإمار اتي، على الرغم من أهميتها.

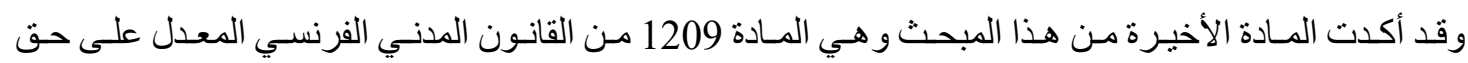

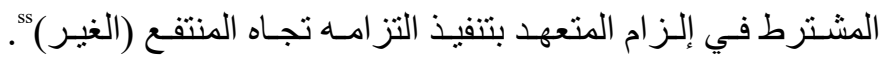

ss L'article 1207 (alinéa 2) de code civil réformé dispose :

« Si elle n>est pas assortie de la désignation d)un nouveau bénéficiaire, la révocation profite, selon le cas, au stipulant ou à ses héritiers ».

$$
\begin{aligned}
& \text { تتص المادة } 1207 \text { (الفقرة الثانية) من القانون المدني المعدل على ما يأتي: } \\
& \text { "إذا لم يقترن الرجوع عن الاشتر اط لمصلحة الغير بتحديد منتفع آخر ، يكون المنتفع - بحسب الحالة - المشترط أو ورثثه). }
\end{aligned}
$$

ss L'article 1207 (alinéa 3) de code civil réformé dispose :

«La révocation produit effet dès lors que le tiers bénéficiaire ou le promettant en a eu connaissance ».

$$
\begin{aligned}
& \text { تتص المادة } 1207 \text { (الفقرة الثالثة) من القانون المدني المعدل على ما يأتي: }
\end{aligned}
$$

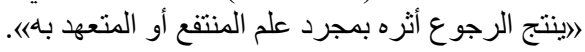

ss L'article 1207 (alinéa 4) de code civil réformé dispose que :

« Lorsqu〉elle est faite par testament, elle prend effet au moment du décès ».

$$
\begin{aligned}
& \text { تتص المادة } 1207 \text { (الفقرة الر ابعة) من القانون المدني المعدل على ما يأتي: }
\end{aligned}
$$

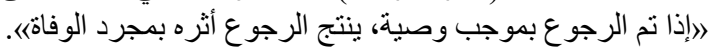

ss L'article 1208 de code civil réformé dispose:

"L'acceptation peut émaner du bénéficiaire ou, après son décès, de ses héritiers. Elle peut être expresse ou tacite. Elle peut intervenir même après le décès du stipulant ou du promettant".

$$
\text { تنص المادة } 1208 \text { من القانون المدني على ما ياتَي: }
$$$$
\text { المتعهدا《. }
$$

ss L'article 1209 de code civil réformé dispose:

"Le stipulant peut lui-même exiger du promettant l'exécution de son engagement envers le bénéficiaire". 


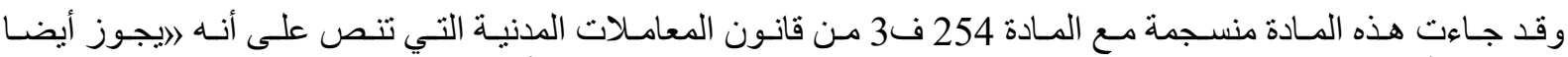

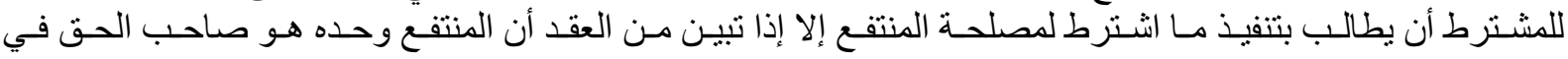

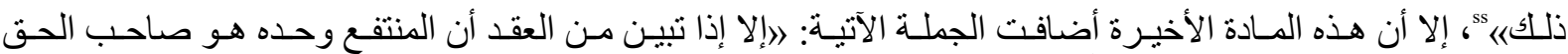

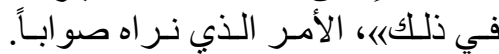

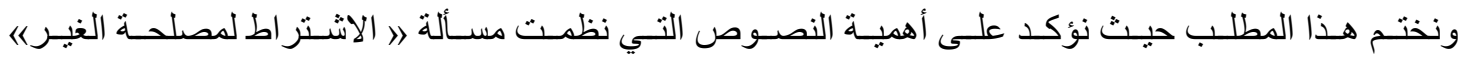

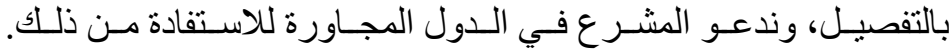

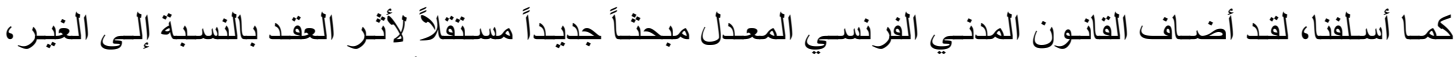

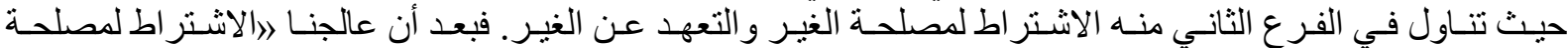

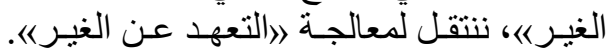

\section{المطلب الثاني: التعهد عن الغير Porte-fort}

\section{3. تعريف التعهد عن الغير}

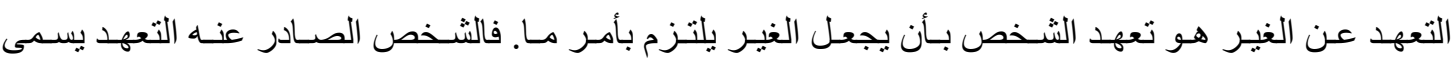

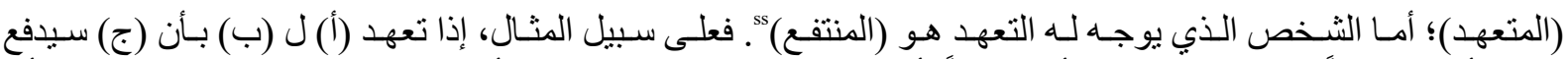

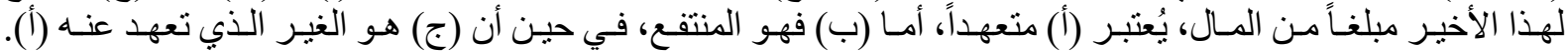

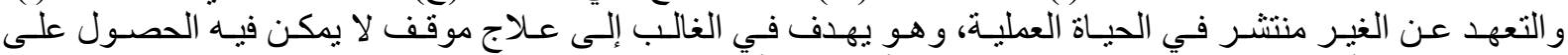

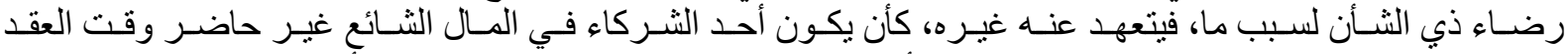

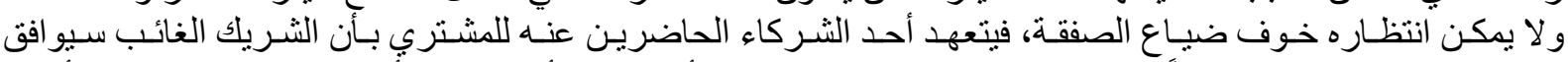

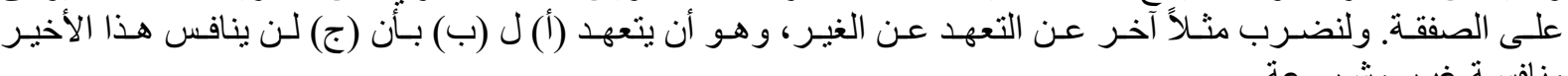
منافسـة غير مشـرو علة.

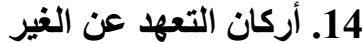

للتعهد عن الغير ثلاثة أركان، نذكر ها تباعاً:

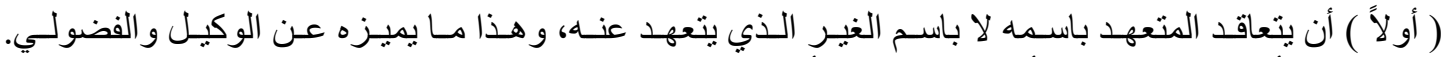

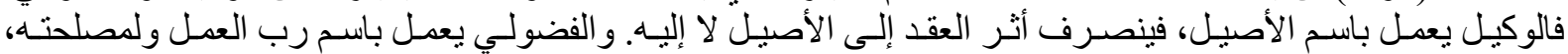

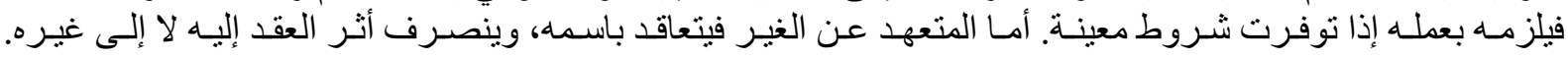

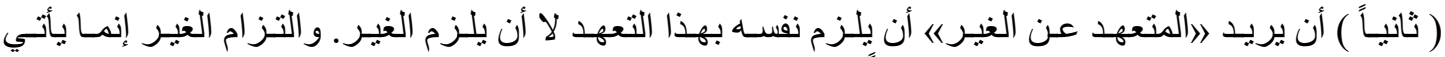

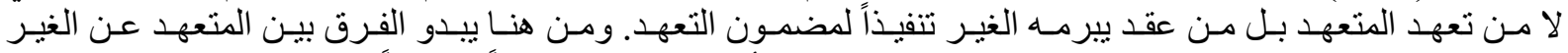

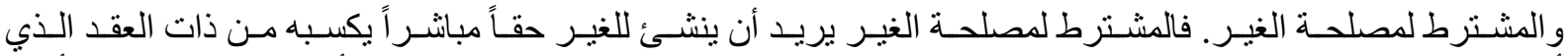

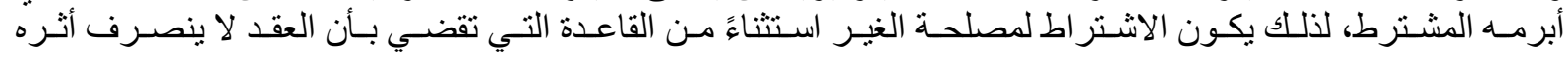
إلى الغير.

\section{تتص المادة 1209 من القانون المدني المعدل على ما يأتي:

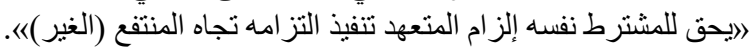

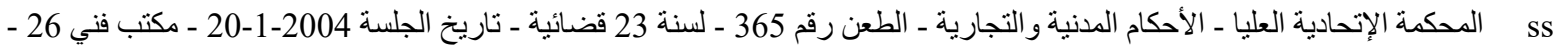

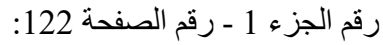

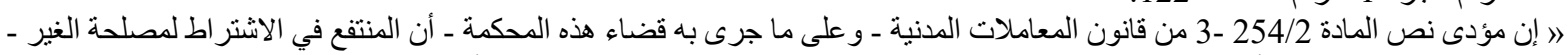

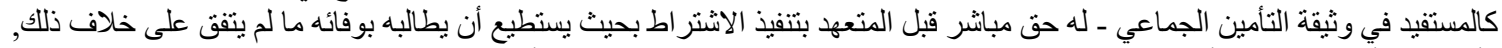

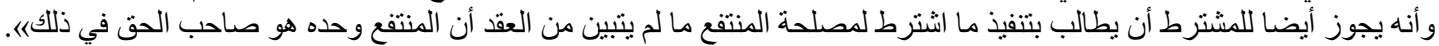

Fages B., Droit des obligations, LGDJ-Lextenso, 8 e éd., 2018, spéc. $\mathrm{n}^{\circ} 94$. 


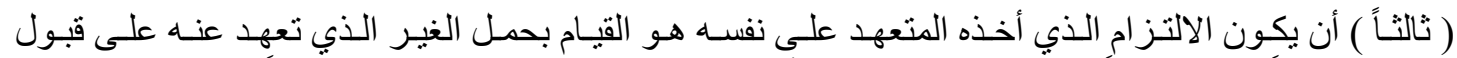

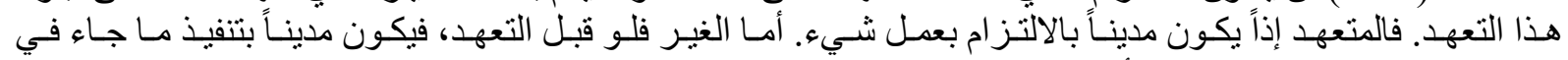

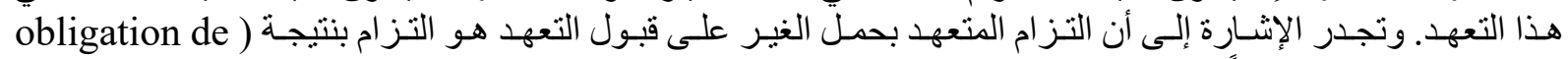
(résultat وليس التزامـاً ببـل عنايـة ( obligation de moyen ).

\section{5 ـاستحداث مادة جديدة مخصصة للتعهز عن الغير}

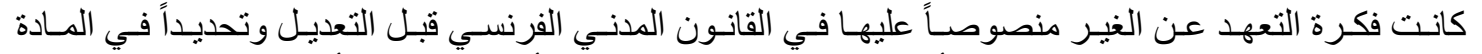

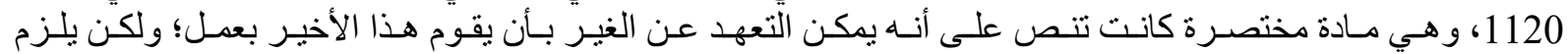

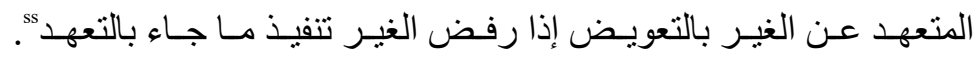

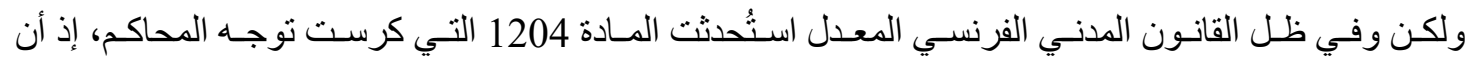

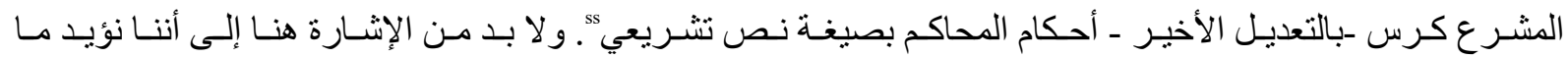

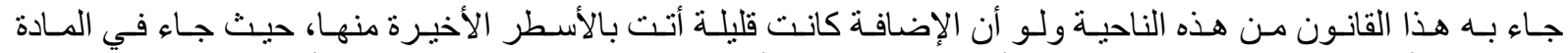

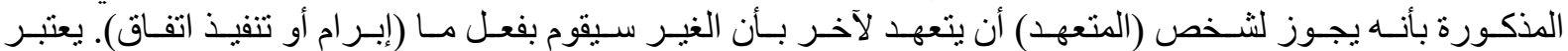

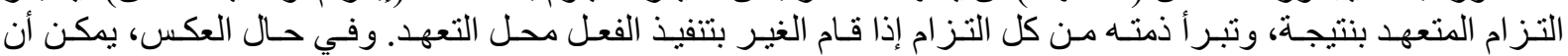

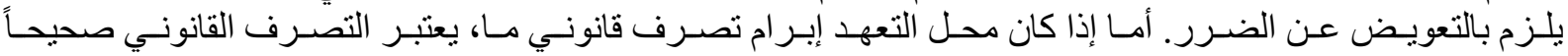

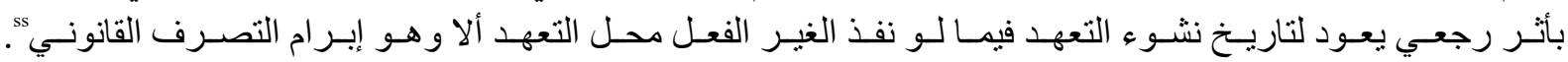

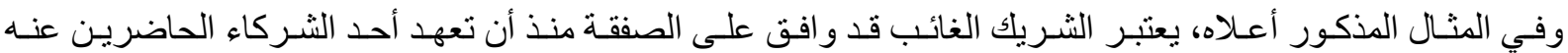

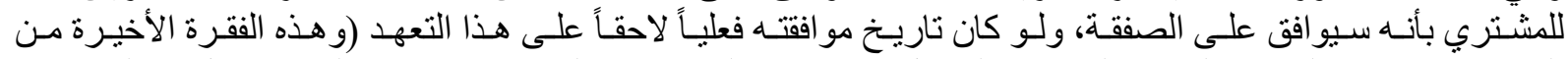

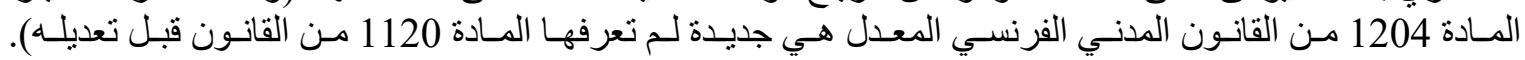

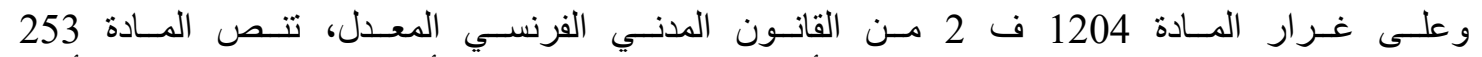

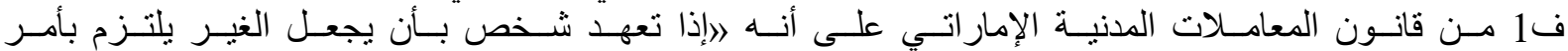

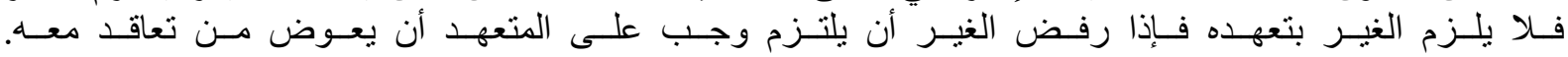

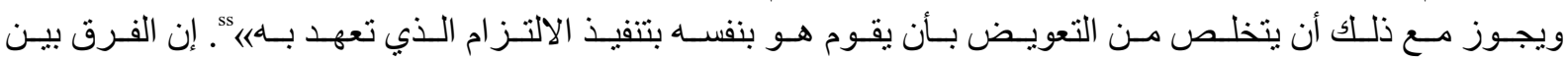

ss L'article 1120 de Code civil avant la réforme dispose:

"Néanmoins on peut se porter fort pour un tiers, en promettant le fait de celui-ci ; sauf l'indemnité contre celui qui s'est porté fort ou qui a promis de faire ratifier, si le tiers refuse de tenir l'engagement".

ss L'article 1204 de code civil réformé dispose :

"On peut se porter fort en promettant le fait d'un tiers.

Le promettant est libéré de toute obligation si le tiers accomplit le fait promis. Dans le cas contraire, il peut être condamné à des dommages et intérêts.

Lorsque le porte-fort a pour objet la ratification d'un engagement, celui-ci est rétroactivement validé à la date à laquelle le porte-fort a été souscrit".

$$
\text { تنص المادة } 1204 \text { من القانون المدني المعدل على ما يأتي: }
$$

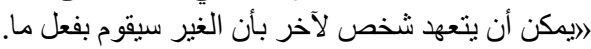

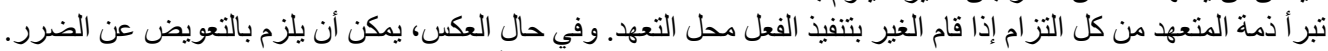

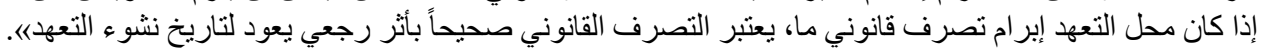

ss Cass. com., 17 juill. 2001, no 98-10.827, Contrats, conc., consom. 2001, comm. 170, note crit. Leveneur L., à propos de la promesse de mise à disposition d'un hélicoptère ; Cass. com., 8 mars 2016, nº 14-24.921, BRDA $6 / 16, n^{\circ} 10$.

ss المحكمة الإتحادية العليا ـ الأحكام الددنية والتجارية ـ الطعن رقم 401 ـ لسنة 25 قضائية ـ تاريخ الجلسة 2005-4-25 - مكتب فني 27 -

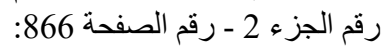

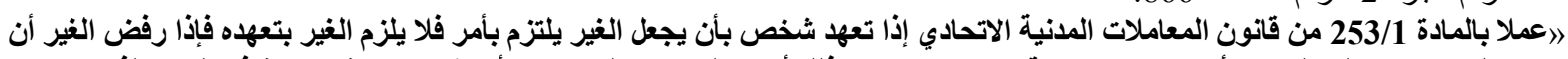

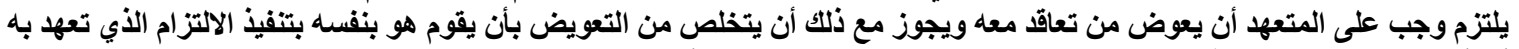

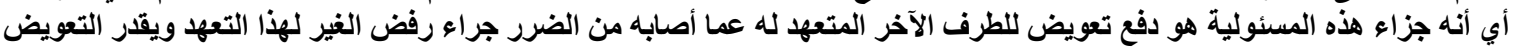

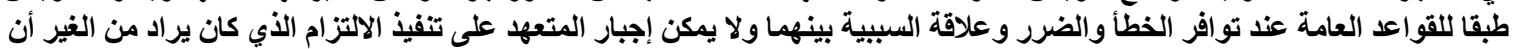

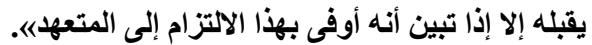

محكمة نقض أبو ظبي ـ الأحكام المدنية و التجارية ـ الطعن رقم 797 ـ لسنة 2008 قضائية ـ تاريخ الجلسة 2009-8-26 ـ مكتب فني 3 - رقم الجزء 2 - رقم الصفحة 1071: 


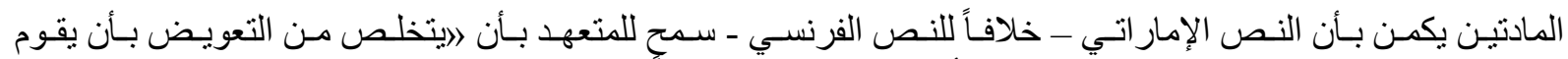

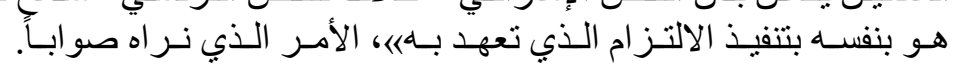

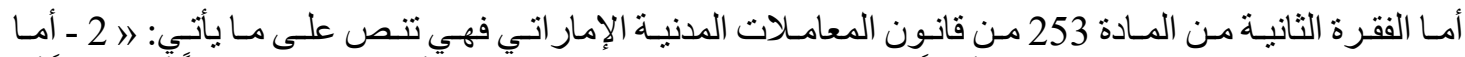

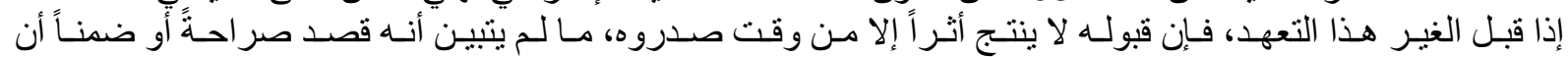

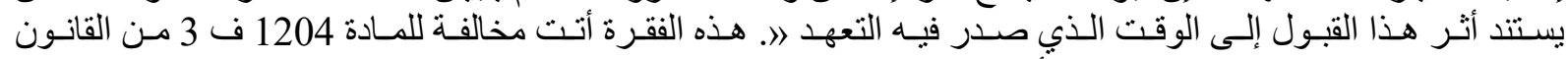

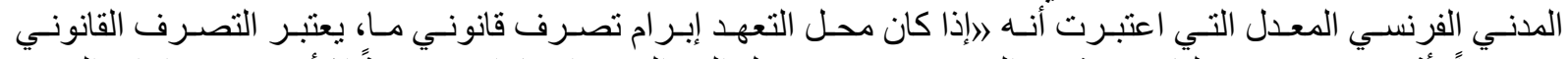

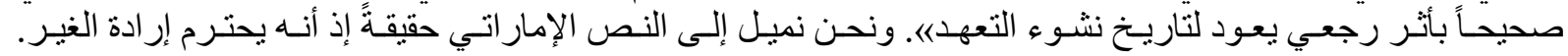

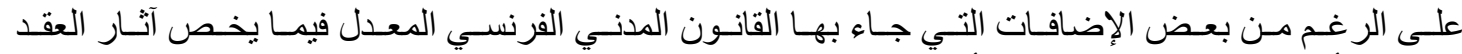

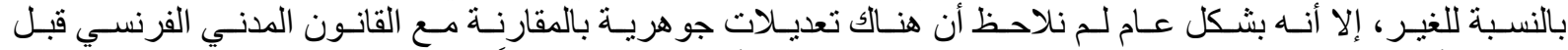

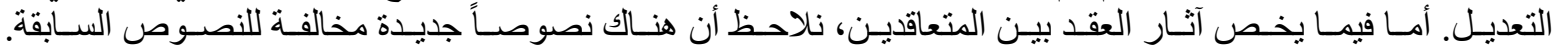

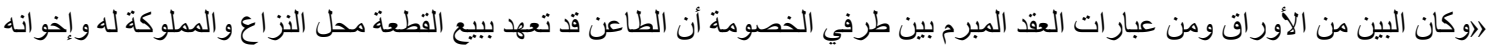

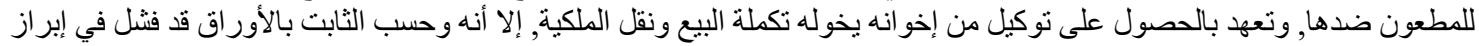

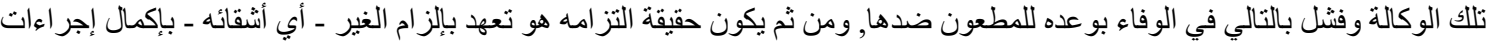

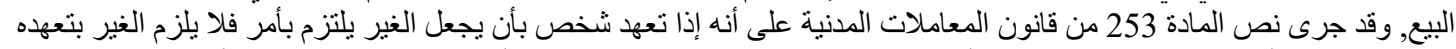

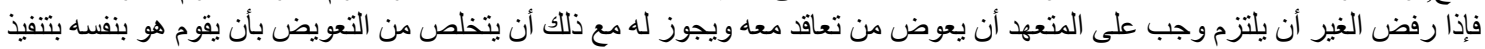

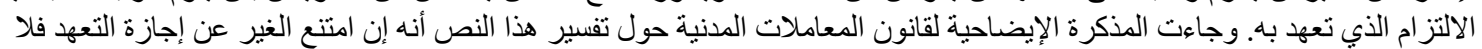

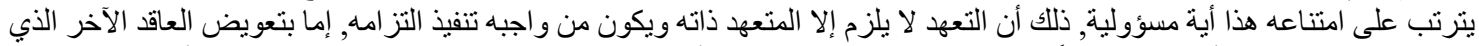

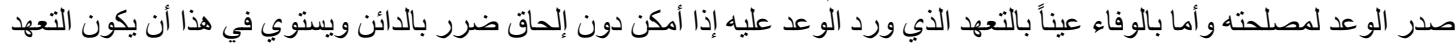
متعلقاً بالتز ام بنقل حق عيني أو بعمل شيء أو بالامتتاع عنهاهـ. 
أهم التعديلات التشريعيت المتعلقتَ بأثر العقد بالنسبت إلى الغير ِِّ القانون المدني الفرنسي المعدل عام 2016 و 2018

\section{الخاتمة}

في ختام هذه الدر اسة، نخرج بعدة نتائج وتوصيات:

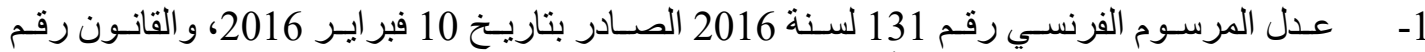

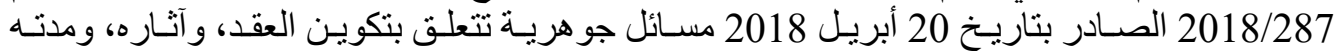

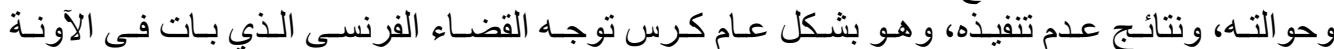

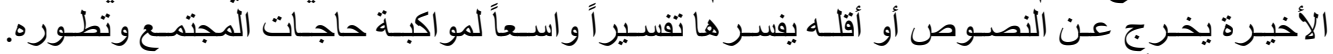

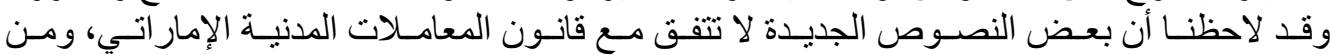

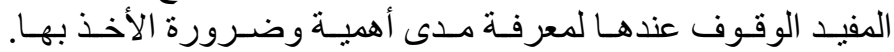

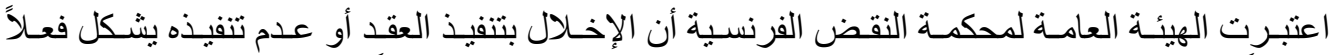

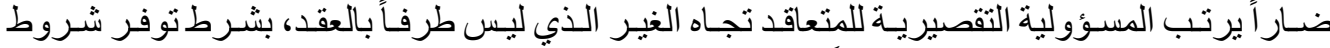

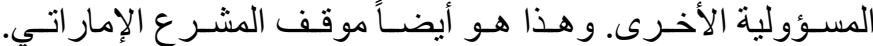

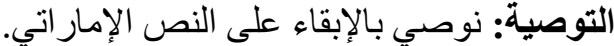

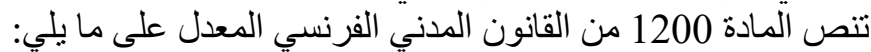

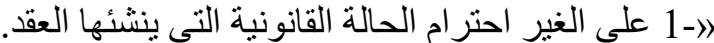

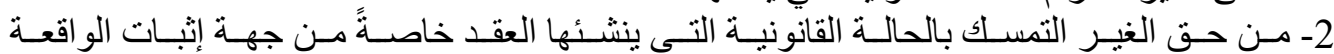

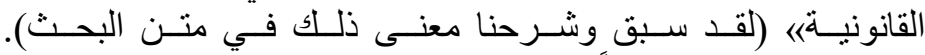

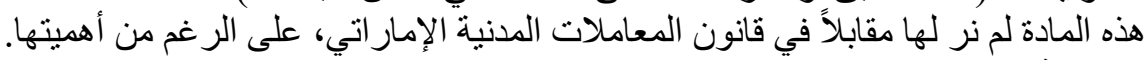

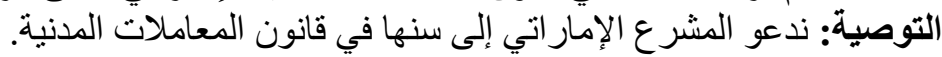

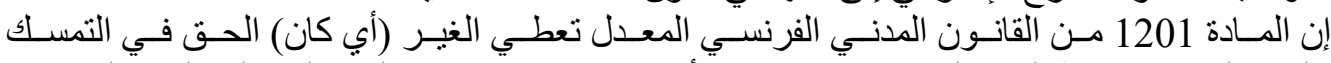

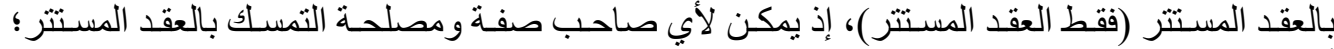

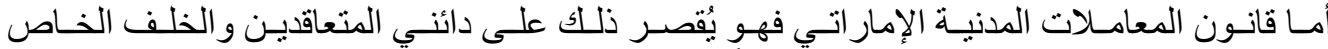

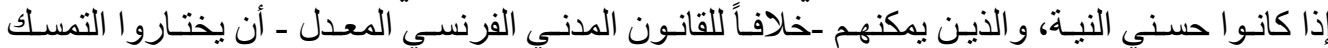

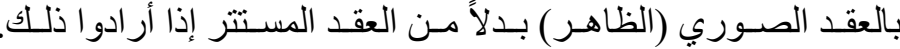

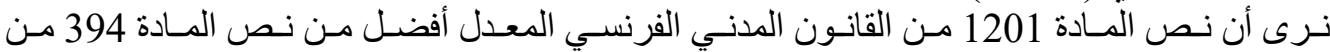

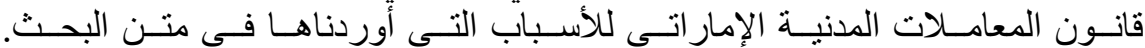

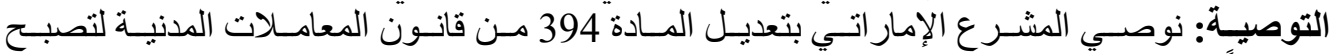

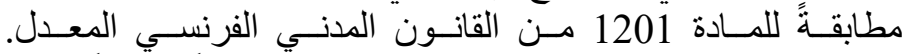

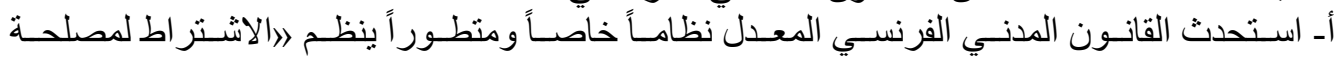

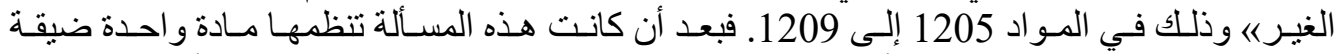

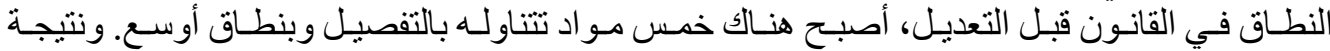

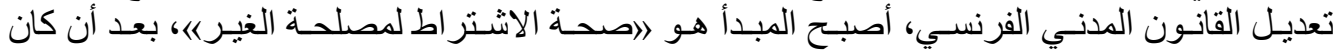

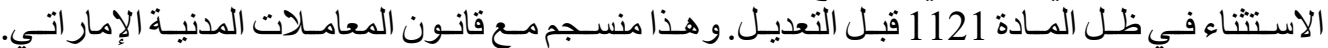

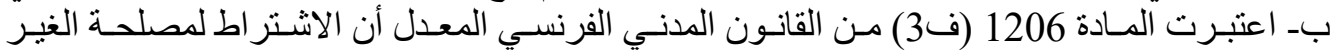

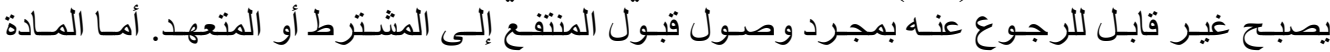

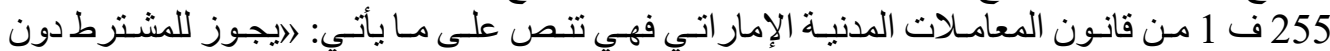

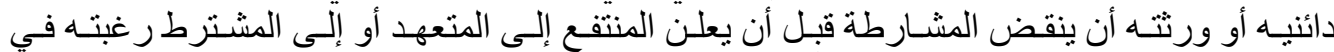

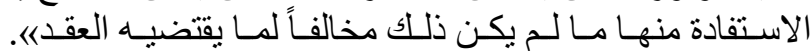

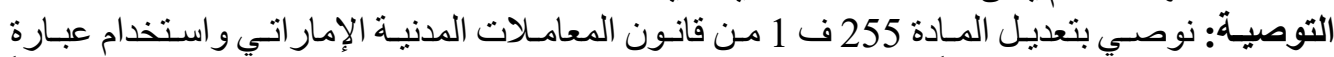

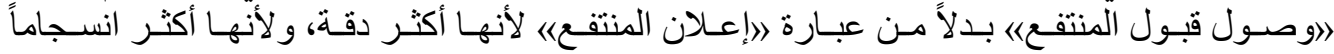

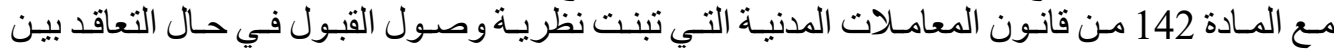

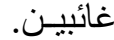

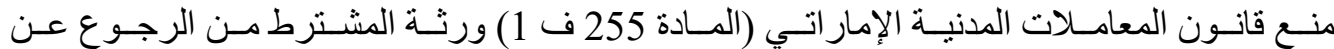

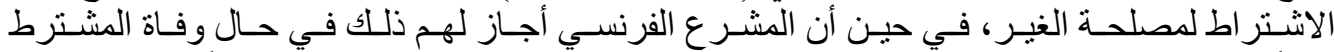

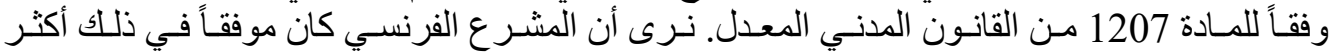
مـن المشــرع الإمار اتسي.

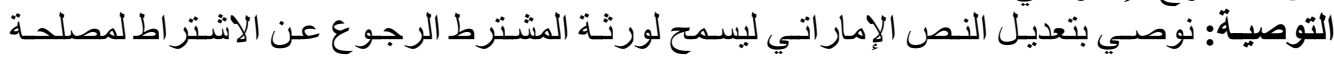

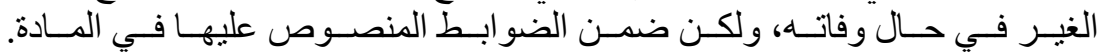

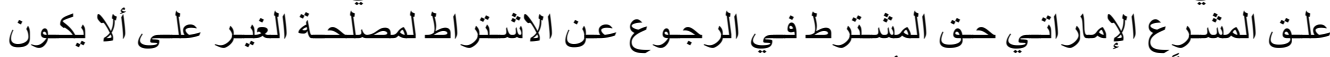

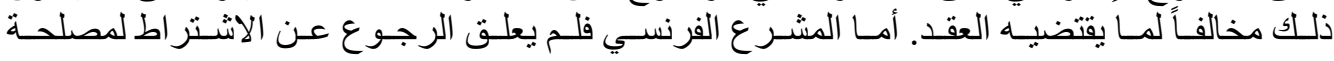


الغير على ذلك. نـرى أن المشـرع الإمار اتـي يعول على إر ادة الطرفين، وبالتالي كان موفقـاً في ذلك

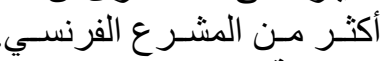
التوصية: نوصي بالإبقاء على النص النص الإمار اتي.

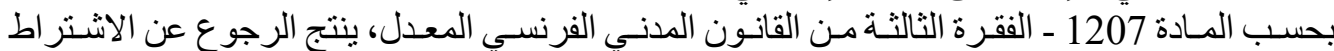

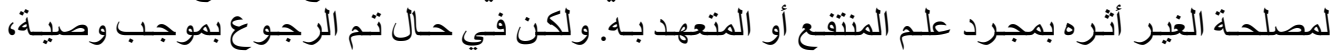

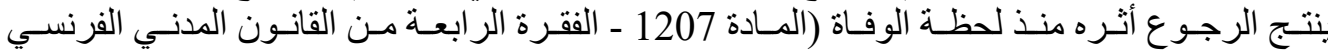

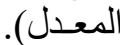

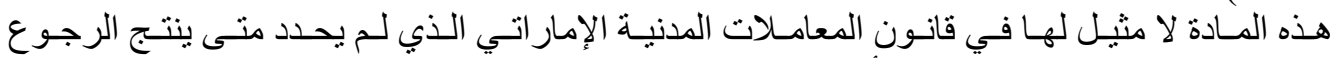

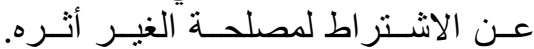
التوصية: نوصي بإضافة مادة مشابهة إلى قانى النون المعان المعاملات المدنية الإمار اتي.

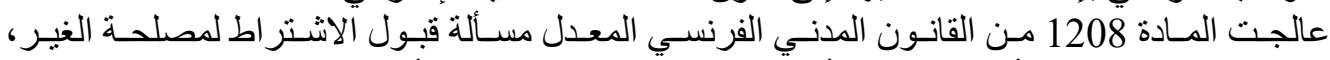

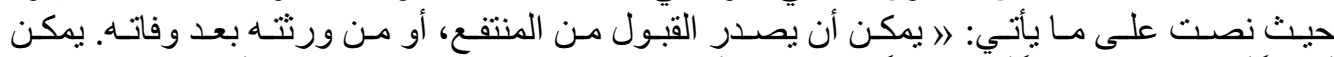

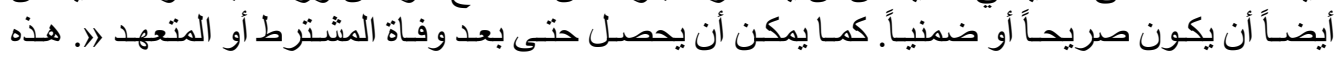

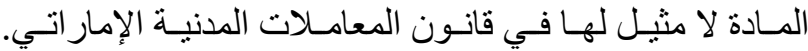

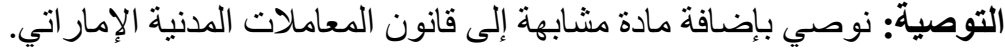

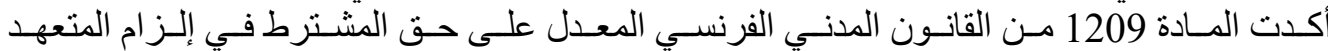

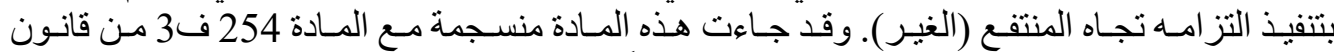

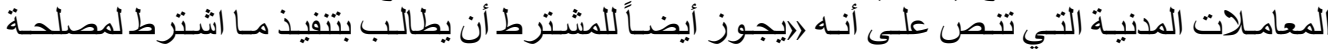

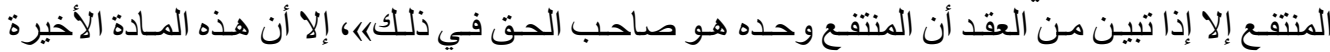

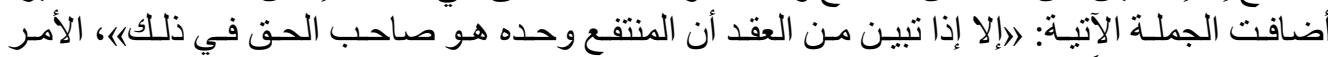

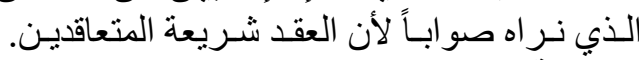
التوصية: نوصي بالإبقاء على النص النص الإمار التئي.

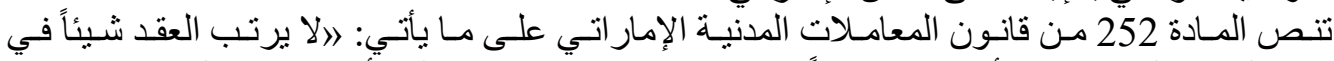

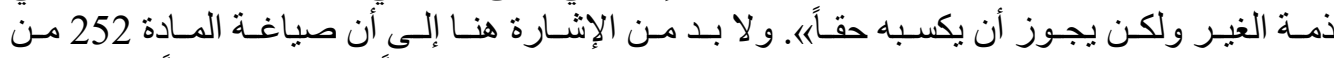

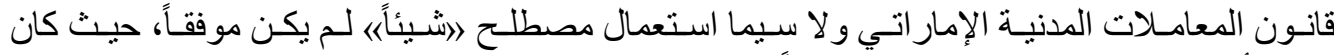

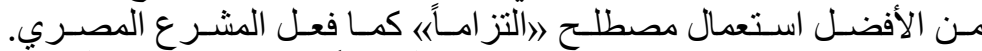

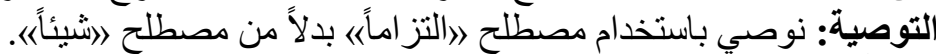

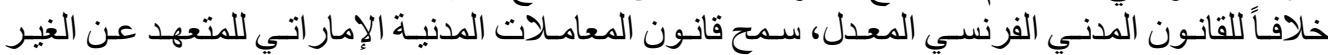

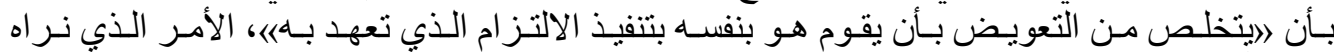

التوصية: نوصي بالإبقاء على النص الإمار اتي. 


\section{قائمة المراجع}

1- G. Chantepie et M. Latina, La réforme du droit des obligations, commentaire théorique et pratique dans l'ordre du Code civil, Dalloz, 2016.

2- $\quad$ Fages B., Droit des obligations, LGDJ-Lextenso, $8^{\mathrm{e}}$ éd., 2018

3- Flour J., Aubert J.-L. et Savaux É., Droit civil. Les obligations. L'acte juridique, t. I, Sirey, 16e éd., 2014.

4- Jamin Ch., La notion d'action directe, préf. Ghestin J., LGDJ, 1991.

5- $\quad$ S. PELLE, «L'effet relatif et l'opposabilité du contrat » in Quel renouveau pour le droit des contrats ?, Dalloz, 2018.

6- $\quad$ Terré Fr., Simler Ph., et Lequette Y., Droit civil. Les obligations, Dalloz, 11éd., 2013.

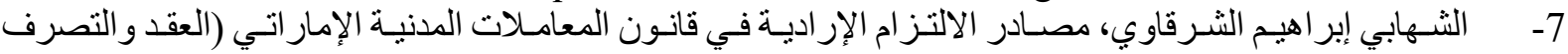

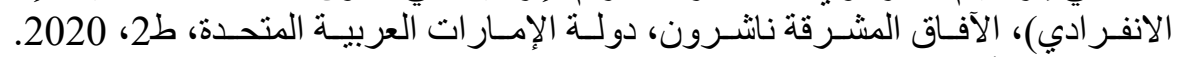

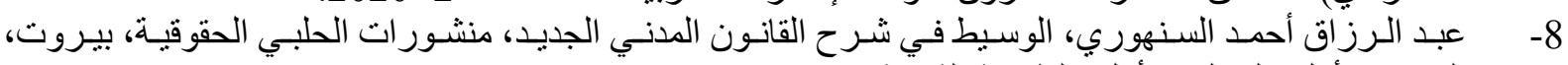

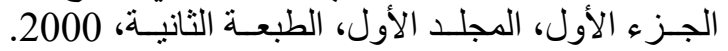

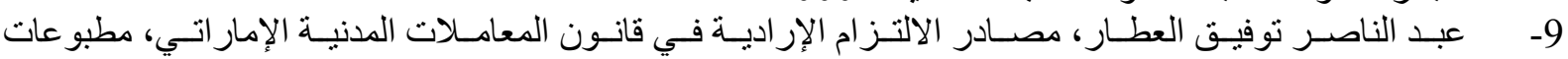
جامعة الإمارات العربية المتحدة، الطبعة الثانية، 2000.

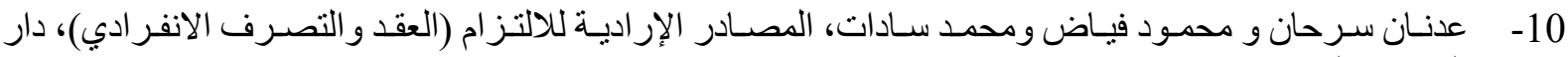
النهضــة العربيـة، مصــر ، 2019.

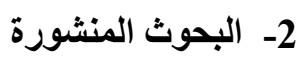

1- $\quad$ Arnaud-Grossi I. et Mestre J., Les piliers du droit des sociétés pourront-ils résister longtemps à la responsabilité délictuelle pour simple manquement contractuel ?, RLDA 2008/24, $n^{\circ} 1425$.

2- $\quad$ Alain Bénabent, L. Aynès, Réforme du droit des contrats et des obligations, D. 2016. 434.

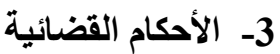

أ- أ- مبالفرنسية

1- Cour de cassation, civile, Chambre civile 1, 9 janvier 2019, 17-14.492 17-17.195, Inédit.

2- $\quad$ Cour de cassation, civile, Chambre civile 1, 9 janvier 2019, 17-27.41.

3- $\quad$ Cour de cassation, civile, Chambre civile 3, 17 mai 2018, 17-16.146, Inédit.

4- $\quad$ Cour de cassation, civile, Chambre civile 1, 21 mars 2018, 17-13.163, Inédit.

5- Cour de cassation, civile, Chambre civile 1, 12 octobre 2016, 15-25.468, Inédit.

6- Cour de cassation, civile, Chambre commerciale, 1 décembre 2015, 14-18.374, Inédit.

7- $\quad$ Cour de cassation, civile, Chambre civile 2, 28 février 2013, 11-27.907, Inédit.

8- $\quad$ Cass. com., 18 janv. $2017 \mathrm{n}^{\circ} 14-16.442$.

9- $\quad$ Cass. com. 19 mars 2015, $\mathrm{N}^{\circ}$ de pourvoi : 13-27199.

10- Cass. $3^{\mathrm{e}}$ civ., 8 juill. 1975, $\mathrm{n}^{\mathrm{o}}$ 73-14.486, Bull. civ. III, $\mathrm{n}^{\circ} 249$.

11- Cass. $1^{\text {re }}$ civ., 26 janv. 1999, nº 96-20.782, Bull. civ. I, n³2, RTD civ. 1999, p. 625, obs. Mestre J.

12- Cass. com., 20 juin 1972, $\mathrm{n}^{\circ}$ 71-11.151, Bull. civ. IV, $\mathrm{n}^{\circ} 198$.

13- Cass. com., 30 nov. 1999, n 97-13.249, RJDA 2000, nº 129.

14- Cass. $1^{\text {re }}$ civ., 17 oct. 2000, n $^{\circ}$ 97-22.498, Bull. civ. I, no 246, D. 2001, p. 952, note Billiau M. et Moury J., JCP G 2001, I, n 338 , obs. Viney G.

15- Cass. 3e civ., 8 juill. 1975, no 73-14.486, Bull. civ. III, no 249.

16- Cass. com., 20 juin 1972, no 71-11.151, Bull. civ. IV, no 198.

17- Cass. req., 27 juill. 1896, DP 1997, I, p. 327.

18- Cass. 1re civ., 3 janv. 1996, no 93-20.404, Defrénois 1996, art. 36381-105. 
19- Ass. plén., 12 juill. 1991, D. 1991, p. 549, note J. Ghestin; Defrénois 1991, 1301, obs. J -L. Aubert.

20- Cass. ass. plén., 6 oct. 2006, no 05-13.255, Bull. civ. ass. plén., no 9, D. 2006, p. 2825 , note Viney G., RLDC 200734/, n 2346, note Brun Ph., RLDA 200611/, n 656, note Jacques Ph., Resp. civ. et assur. 2006.

21- Cass. Civ. $3{ }^{\text {e }}, 22$ oct. 2008, Bull. civ. 111, 160 ; Cass. civ $1{ }^{\text {re }}, 15$ déc. 2011, n. 10-17691.

22- Cass. com., 7 oct. 1997, nº 95-18.119, Bull. civ. IV, n²51, RJDA 1997, nº 1498, JCP G 1998, I, no 131, note Caussain J.-J. et Viandier A., RTD civ. 1998, p. 902, obs. Mestre J., Bull. Joly Sociétés 1997, p. 1058, note Mousseron P., D. 1998, p. 112, note Delebecque $\mathrm{Ph}$.

23- Cass. com., 17 juill. 2001, n ${ }^{\circ}$ 98-10.827, Contrats, conc., consom. 2001, comm. 170, note crit. Leveneur L.

24- Cass. com., 8 mars 2016, $\mathrm{n}^{\circ}$ 14-24.921, BRDA 6/16, $\mathrm{n}^{\circ} 10$.

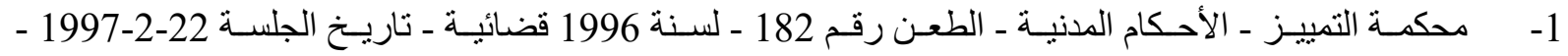

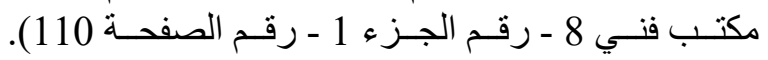

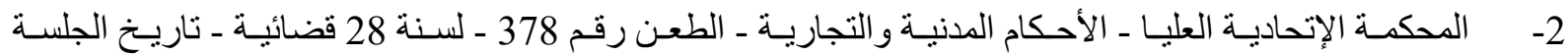

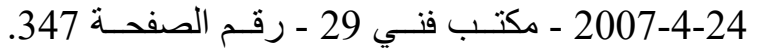

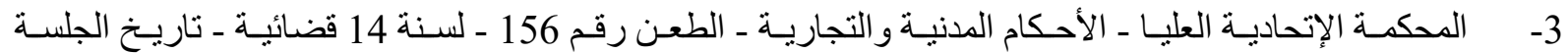

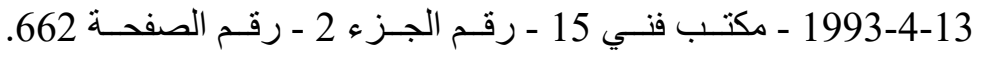

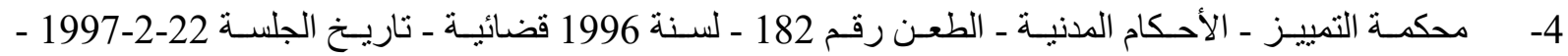

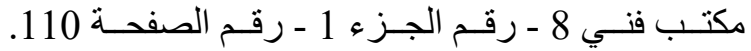

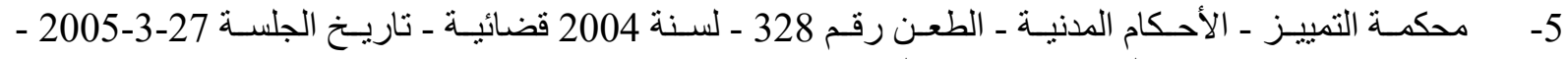

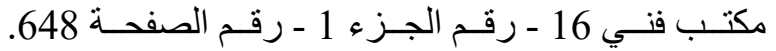

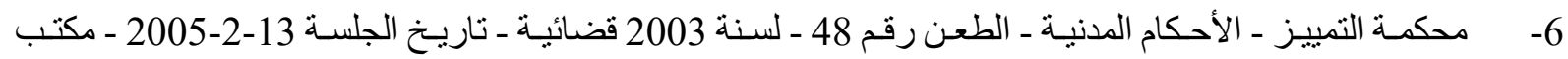
فنـي 16 - رقم الجزءء 1 - رقم الصفحـة 297.

7- محكمـة التمبيـز ـ الأحكام المدنيـة ـ الطعن رقم 29 ـ لسـنة 2010 قضائيـة ـ تناريخخ الجلسـة 16-5-2010 - رقم الصفحـة 143.

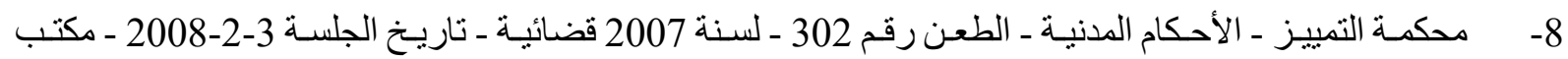

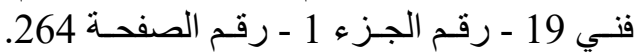

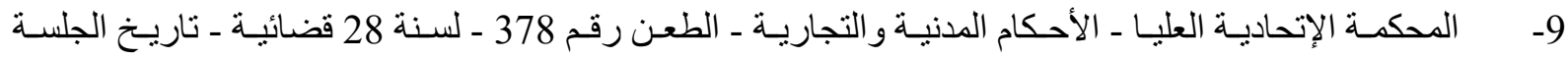

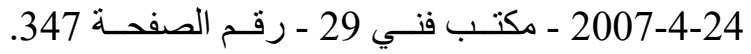

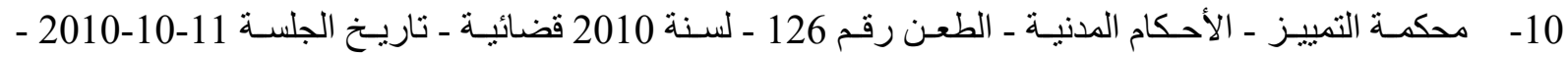

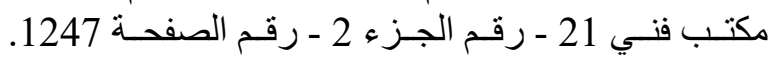

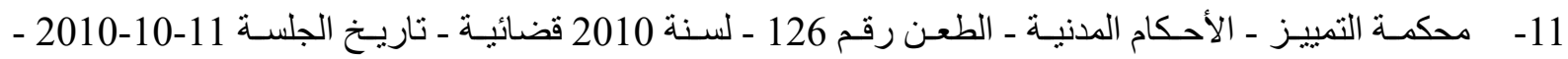
مكتب فنـي 21 - رقـم الجـزء 2 ـ رقـم الصفحـــ 1247. 
أهم التعديلات التشريعيت المتعلقتَ بأثر العقد بالنسبت إلى الغير ِِّْ القانون المدني الفرنسي المعدل عام 2016 و 2018

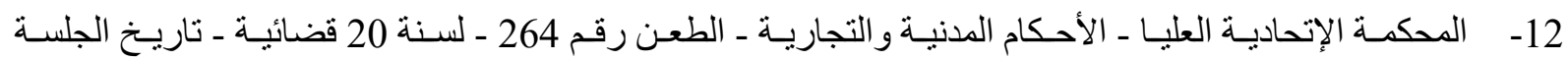

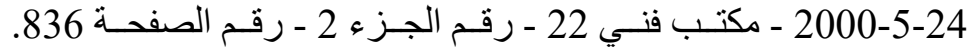

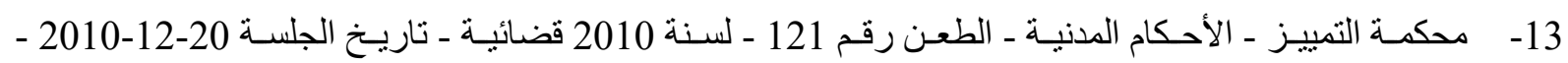

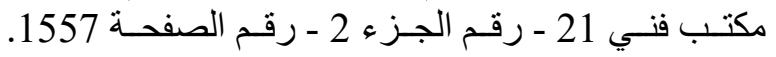

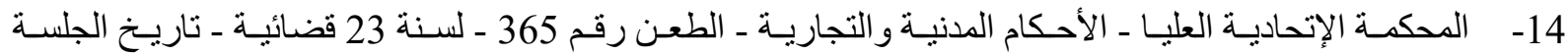

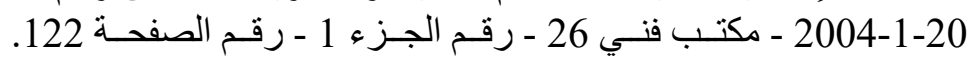

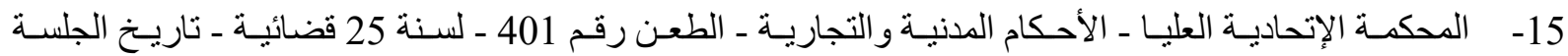

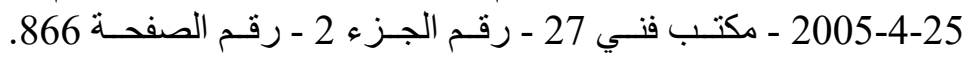

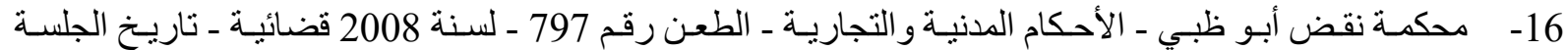
2009-8-26 - مكتب فنـي 3 - رقـم الجـزء 2 - رقـم الصفحـة 1071. 